\title{
Deleterious Effect of Maternal administration of Acrylamide on Lung Development and the Prospective Effect of Ascorbic Acid: Pertinent Role of Serum Endocan
}

Original Article

\author{
Marwa M. Ahmad', Amira E. Alsemeh ${ }^{1}$ and Ola E. Nafea ${ }^{2}$ \\ Departments of Anatomy and Embryology ${ }^{l}$, Clinical Toxicology '2, Faculty of Medicine, \\ Zagazig University, Egypt
}

\begin{abstract}
Introduction: Acrylamide (ACR) is an environmental pollutant that is present in surrounding environment and Western-style carbohydrate-rich foodstuff and tobacco smoke.

Aim of the Study: The aim of the study was to assess the potential histological changes in the lung of nascent rats as a consequence to maternal ACR administration and the possible protective role of ascorbic acid (ASA) in rat offspring.

Materials and Methods: Pregnant rats were randomly assigned into four groups, negative control group, ASA group $(100 \mathrm{mg} / \mathrm{kg} / \mathrm{day})$, ACR group $(10 \mathrm{mg} / \mathrm{kg} / \mathrm{day})$ and ACR+ASA group. Ten pups from each group were sacrificed. Biochemical, histological and morphometric techniques were used to determine the effect of ACR and ASA on lung development in the offspring on postnatal days (PND) 2 and 21.

Results: The results showed that ACR administration during gestational and lactation periods significantly increased the serum endocan and the lung malondialdehyde (MDA) but decreased the lung reduced glutathione (GSH) along with severe histopathological changes proved ultra-structurally. Morphometric results revealed significant increase thickness in interalveolar septa among ACR group. Concurrent administration of ASC with ACR during gestation period attenuated most of the cytoarchitecture alterations of the developing lungs.

Conclusion: Maternal administration of acrylamide resulted in harmful impact on the lung histological structure of rat's offspring through its oxidative stress and inflammatory mechanisms. Co-administration of ASA along with ACR can ameliorate this deleterious impact through its antioxidant and anti- inflammatory properties.
\end{abstract}

Received: 02 July 2019, Accepted: 15 Septemper 2019

Key Words: Acrylamide, ascorbic Acid, endocan, lung development.

Corresponding Author: Marwa Mahmood Ahmad, MD, Anatomy and Enmbryology, Faculty of Medicine, Zagazig University, Zagazig, Egypt, Tel.: +20 55 2373139, E-mail: marwaahmed515@gmail.com

ISSN: 1110-0559, Vol. 43, No. 1

\section{INTRODUCTION}

A group of maternal, placental and fetal factors are engaged in ensuring the normal fetal growth. Nutrition has a major role in the early structural development of mammals and has long-term effects that are obvious until later in life ${ }^{[1]}$.

Fetal development is highly sensitive to exposure to xenobiotics that influences the physiological responses of the offspring, but adequate maternal nutrition reduces the risk of maternal, fetal effects and long-term effects in progeny ${ }^{[2,3]}$.

Humans are born with lung development almost complete; conversely, rats are born in a saccular stage, and alveolar maturation is completed by PND $21^{[4]}$. Therefore, the selected age groups in the current study were based on the different postnatal stages of lung development: the saccular stage at PND 2 and the alveolar maturation stage at PND 21.
Acrylamide (ACR) is a colorless and odorless chemical contaminant produced industrially formed by the hydration of acrylonitrile. It is widely used in the treatment of wastewater, paper/pulp manufacturing, mining, scientific research, surface coatings, textile and cosmetics ${ }^{[5]}$.

There is high concentrations of ACR in carbohydraterich foods processed at temperatures exceeding $120^{\circ} \mathrm{C}$ and containing low moisture, such as French fries, potato chips, bread, biscuits, and coffee ${ }^{[6]}$. In addition, tobacco smoking is an important source of human exposure to $\mathrm{ACR}^{[7]}$.

It is well known for its potential health hazards. ACR exposure is associated with neurotoxicity ${ }^{[8]}$, carcinogenesis $^{[9]}$, genotoxicity ${ }^{[10]}$, cytotoxicity ${ }^{[11]}$, and reproductive toxicity ${ }^{[12]}$.

Acrylamide is absorbed mainly via oral, dermal and respiratory routes, and it has low molecular weight and high water solubility,; therefore, it can easily cross biological membranes, including blood-placenta and blood-milk barriers $^{[13,14]}$. 
It negatively affects health through several mechanisms; e.g. ACR attacks biological moieties via interactions between its active vinyl group, and the $\mathrm{SH}$ and $\mathrm{NH} 2$ groups of proteins or the nitrogen atoms of nucleic acids ${ }^{[15]}$.

Other mechanisms of ACR toxicity include disruption of cytoskeletal integrity, oxidative stress, inflammation, apoptosis induction and epigenetic alteration ${ }^{[11,16]}$. Thiolrich molecules, e.g., glutathione (GSH), albumin and hemoglobin, are the principle ACR scavengers ${ }^{[17]}$.

Ascorbic acid (ASA) is an essential micro-nutrient involved in several metabolic pathways that has several health benefits, such as antioxidant, anti-carcinogenic, immune-modulatory and anti-inflammatory effects ${ }^{[18]}$.

Endocan, is an endothelial cell activation marker, formerly identified as endothelial- specific molecule-1 (ESM-1), is a product of endothelial cells that was, first identified in 1996 in lung endothelium. It plays an important role in many endothelial-dependent pathophysiological diseases. Many studies have shown that endocan can be used as a biomarker for the assessment of inflammatory, cardiovascular, and chronic kidney diseases as well as cancer $^{[19]}$.

Endocan has anti-inflammatory properties in acute lung injury (ALI), ${ }^{[20]}$ and its expression in human lung and renal tissue may play a role in angiogenesis associated with organ-specific inflammation ${ }^{[21]}$.

Currently, natural, safe antioxidants that do not cause side effects are needed. In addition, the studies on the ACR -induced effects on the postnatal lung development are few. Therefore, the present study used a weaning rat model to study the potential developmental toxicity of ACR on histological structure of lung and the possible protective role of ASA.

\section{MATERIALS AND METHODS}

\section{Chemicals}

- $\quad$ ACR (99\% pure form) was purchased from Sigma Chemical Company, (St. Louis, MO, USA)

- ASA (pure powder) was purchased from Elgomhoria Company for Chemical and Medical Trading, Zagazig, Egypt).

\section{Readymade Kits}

- $\quad$ Reduced Glutathione (GSH) detection kits were purchased from (Biodiagnostic, Cairo, Egypt).

- MDA content (lipid peroxides) detection kits were purchased from (Biodiagnostic, Cairo, Egypt).

- Serum endocan concentrations (Rat ESM-1 ELISA Kit) were purchased from Bioassay Technology Laboratory, Shanghai, China)

\section{Experimental animals}

Twenty-four adult female albino rats weighing 140-180 g were obtained from Zagazig Scientific and
Medical Research Center (ZSMR) and maintained at the Breeding Animal House of Faculty of Medicine, Zagazig University, Egypt. Animals were kept for acclimatization in separate hygienic stainless-steel cages at a controlled temperature $\left(23 \pm 2^{\circ} \mathrm{C}\right)$ and humidity $(60 \pm 5 \%)$ in a $(12: 12-\mathrm{h}$ light: dark cycle) artificially illuminated room, completely free from chemical contamination. The animals were fed with the standard laboratory food and allowed free access to it and water. All animals were acclimatized to laboratory conditions for ten days before the start of experiments. All animals received human care in compliance with the Animal Care Guidelines of the National Institutes of Health (NIH), Zagazig University. The ZU-IACUC Committee approved the protocol (no. ZU-IACUC/3/F/95/2018).

\section{Experimental design}

Female rats were mated with males (2:1) in each cage. We inspected the female rats daily for the presence of a vaginal plug (a whitish mass), which indicated day zero (D0) of pregnancy. Then, we randomly assigned the animals into four groups of six rats each. The dams in group 1 were administrated distilled water orally by intragastric tube and served as negative controls. The rats in group 2 (ASA group) orally administrated $100 / \mathrm{mg} / \mathrm{kg}$ dissolved in distilled water ${ }^{[22]}$ (500 $\mathrm{mg}$ ASA dissolved in $50 \mathrm{~cm} 3$ distilled water to get a solution for each $1 \mathrm{~cm} 3$ contains 10 $\mathrm{mg}$ and given $1 \mathrm{~cm} 3 / 100 \mathrm{gm}$. /day and served as positive controls. The dams in group 3 (ACR group) orally received $10 / \mathrm{mg} / \mathrm{Kg}^{[23]}$. ACR prepared by dissolving 30mg ACR in $30 \mathrm{~cm} 3$ distilled water to get a solution for each $1 \mathrm{~cm} 3$ contains $1 \mathrm{mg}$ and given $1 \mathrm{~cm} 3 / 100 \mathrm{gm}$. The dams in group 4 (ACR+ASA group) were orally administrated the same doses of ACR and ASA as in groups 2 and 3.

The dams were administrated ACR and ASA from gestational day (GD) 7, through parturition and lactation until weaning at postnatal day (PND) 21. At PND 2 and PND 21, ten pups (male and female) from each group were sacrificed. Lung tissues were collected for histopathological and biochemical studies (Figure 1).

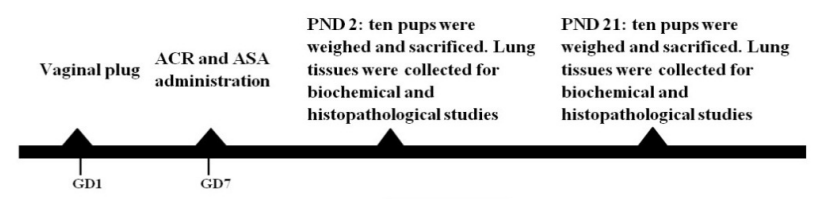

Fig. 1: Scheme for the experimental protocol Abbreviations, GD, gestational day; PND, postnatal date; ACR, acrylamide; ASA, ascorbic acid

\section{Blood sample collection and serum separation}

Twenty four hours after the last administration, the pups in all groups were anaesthetized intraperitoneally with pentobarbital $(60 \mathrm{mg} / \mathrm{kg} / \text { body weight })^{[24]}$ and blood samples were immediately obtained from the retro-orbital venous plexus of each rat, using a fine heparinized capillary tube introduced into the medial epicanthus of the eye. The blood samples were collected then centrifuged using a 
Remi cool centrifuge at 3000 (round per minute) for 20 min. The supernatant serum was collected in a clean, dry tube for estimation of serum endocan.

All biochemical procedures were carried out in the Central Research Laboratory, Faculty of Medicine, Zagazig University.

The lungs were dissected gently and divided into three parts. The samples from the first part were processed for light microscopic examination, while those in the second part were processed for electron microscopic examination. The samples in the last part were homogenized in ice-cold phosphate buffer $(\mathrm{pH} 8)$ at a concentration of $15 \%(\mathrm{w} / \mathrm{v})$ for assessment of reduced glutathione (GSH) levels and the lipid peroxidation (as malondialdehyde, MDA).

\section{Biochemical studies}

\section{Serum endocan analysis}

Serum endocan concentrations were measured using specific kits in accordance with the procedures specified by the manufacturers.

\section{Assessment of lipid peroxidation and GSH activity}

Lung tissues were minced and homogenized, separately, in ice-cold sodium and, potassium phosphate buffer $(\mathrm{pH})$ at a concentration of $15 \%(\mathrm{w} / \mathrm{v})$ in Scientific Research Centre, Faculty of Medicine, Zagazig University. The homogenate was centrifuged at $110000 \times \mathrm{g}$ for 20 min at $4{ }^{\circ} \mathrm{C}$, and the resultant supernatant was used for the determination of lung MDA and GSH concentrations. The levels of both lung MDA and GSH in the lungs were colorimetric-ally assayed according to the methods of some authors ${ }^{[25,26]}$, respectively.

\section{Lung tissue preparation for histological examination}

\section{Light microscopic examination}

Representative specimens from the right lower lobe of the lung were immediately fixed in $10 \%$ neutral buffered formalin for $24 \mathrm{~h}$, washed and dehydrated with conventional ascending grades of alcohol, cleared in xylol, then embedded in paraffin. Then, $5 \mu \mathrm{m}$ thick sections were stained with haematoxylin and eosin (H\&E) for studying the histopathological structures of the lungs ${ }^{[27]}$. All stained slides were examined by light microscopy (Leica ICC50W) in the Image analysis unit of the Department of Anatomy and Embryology, Faculty of Medicine, Zagazige University.

\section{Electron microscopic examination}

Small pieces of the right lung were immediately fixed in $2.5 \%$ glutaraldehyde buffered with $0.1 \mathrm{M}$ phosphate buffers at $\mathrm{pH} 7.4$ for $2 \mathrm{~h}$ at $4{ }^{\circ} \mathrm{C}$ and then, post-fixed in $1 \%$ osmium tetroxide in the same buffer for $1 \mathrm{~h}$ at $4{ }^{\circ} \mathrm{C}$. The specimens were processed and embedded in EMmbbded- 812 resin capsules at $60^{\circ} \mathrm{C}$ for $24 \mathrm{~h}$. Semithin sections $(1 \mu \mathrm{m})$ were mounted on glass slides and stained with toluidine blue and examined by light microscopy. Ultrathin sections were obtained using a Lecia Ultracut UCT (Germany), stained with uranyl acetate and lead citrate ${ }^{[28]}$ and then examined using a JEOL-JEM 1010 electron microscope (Tokyo, Japan) at the Mycology and Regional Biotechnology Center, Al Azhar Boys University, Cairo, Egypt.

\section{Morphometric analysis}

H\&E- stained sections were examined to measure the thickness of primary inter-alveolar septa using a Leica QWin 500 image analyzer (Leica Ltd, Cambridge, UK) in the Image analysis unit of the Department of Anatomy and Embryology, Faculty of Medicine, Zagazig University. All measurements were taken at $400 \times$ magnifications from ten non-overlapping visual fields from five serial sections for each rat in each group.

\section{Statistical analysis}

Continuous variables are expressed as the mean $\pm \mathrm{SD}$. We used one-way ANOVA to detect significant differences between groups followed by Tukey's post hoc test for multiple comparisons between groups. The threshold for significance was at $P<0.05$.

We analyzed the data using GraphPad Prism, Version 7.0 software.

\section{RESULTS}

\section{Mortality}

Three rat offspring of ACR-exposed mothers died on PND 21.

\section{Serum endocan concentrations and, MDA and GSH levels in lung tissue}

No significant change in Serum endocan concentrations, MDA and GSH levels in lung tissue in control rat's offspring compared with those administrated ASA. Maternal ACR administration during gestation and lactation significantly increased serum endocan concentrations and lung MDA levels and decreased lung GSH levels in the rat offspring at PND 2 compared to the control group $(P<.05)$. The protective effects of ASA were proven by significant decrease in serum endocan concentrations and lung MDA levels along with significant increase in GSH levels in the in lung tissue of ACR+ASA group compared to ACR group $(P<.001)$ (Table 1). At PND 21, also ACR-group revealed significant increase in serum endocan concentrations and lung MDA levels with decreased lung GSH levels when compared with the control group $(P<.05)$, while ASA co-administration significantly reduced serum endocan concentrations and lung MDA levels with significant elevation in GSH levels compared with ACR- group $(P<.001)$ (Table 2). 


\section{Histological results}

Light microscopic examination of lung tissue at $2^{\text {nd }}$ postnatal day (PND 2)

\section{$H \& E$ stained sections}

H\&E stained sections from the lungs of control rat's offspring and those administrated ASA were nearly of the same appearance; control rats showed normal spongy lung architecture composed mainly of smooth outlined saccules comprising primitive air spaces and bronchial passages. Primary septa of variable thickness appeared and separated the saccules and short, thick secondary septa projecting into the saccular lumens (Figure 2). In the lung tissues of ACR-group, the primary septa separating the saccules appeared thicker than those in the control offspring, comprising many layers of interstitial cells with variablesized saccules (Figure 3a). Bronchus with hyperplastic epithelium and focal infiltration of mononuclear cells was also observed in addition to dilated congested blood vessels with irregular lumen (Figure 3b). However, partial improvement in lung tissues of ACR+ ASA group was evident, as demonstrated by apparent decreased thickening of the primary septa in comparison with ACR-group and the presence of apparently normal blood vessels with flat endothelial cells and small secondary septa (Figure 4).

Toluidine blue-stained sections of lung tissue at $2^{\text {nd }}$ postnatal day (PND 2)

Toluidine blue-stained sections from the lungs of control rat's offspring and those administrated ASA had nearly the same appearances; control rats showed saccules were lined with two types of cells: cells with large, rounded, pale nuclei and others with flat nuclei. The primary septa consisted of interstitial cells, some of which had large, pale nuclei while; others had dark nuclei. Many blood capillaries were observed on both sides of the primary septa (a double capillary network) and at the secondary septa, which bulged into the lumens of the saccules (Figure 5). In the ACR group, the lung tissues revealed that, the saccular walls had cells with large, round, pale nuclei similar to those in the control rats; however, cells with flat nuclei were difficult to detect. The primary septa were markedly thickened, with a large number of differently shaped interstitial cells (Figure 6). In the ACR+ ASA group, the primary septa were thinner than those in the ACR- group, and many secondary septa with double blood capillaries were observed (Figure 7).

\section{Electron microscopic examination of lung tissue at $2^{\text {nd }}$ postnatal day (PND 2)}

Ultrathin sections from the lungs of control rat's offspring and those administrated ASA were nearly of the same appearances; control rats showed inter-saccular septa consisted of groups of interstitial cells; some of the cells had large, rounded, euchromatic nuclei with vacuoles and electron- dense bodies (lipid droplets) within the cytoplasm, while others had elongated nuclei and the cytoplasm devoid of lipid droplets., Capillaries were observed on both sides of the septa (Figure 8a). Regarding the lining of the saccules, cuboidal cells with rounded, euchromatic nuclei, lamellar bodies and few microvilli were observed (Figure 8b). In ACR group, the lung tissues showed that, the inter-alveolar septa were formed of many layers of interstitial cells, some of them revealed irregular and shrunken nuclei (Figure 9a). Type II pneumocytes (PIIs) appeared within the saccular lumens with irregular, heterochromatic nuclei. Microvilli were also observed. Many blood capillaries were seen within the saccular walls in addition to mononuclear cells most probably neutrophils (Figure 9b). In the lung tissues of ACR+ASA group, the saccular walls showed fewer different types of interstitial cells and more lipid droplets than those in the lungs of ACR rat offspring (Figure 10a). The PIIs had large, rounded, euchromatic nuclei with lamellar bodies. Mitochondria, few apical microvilli and Lipid droplets could also be seen (Figure 10b).

The air-blood barriers in the control lung tissues, were formed of the attenuated type I pneumocyte (PI), cytoplasm, fused basal laminae and capillary endothelial cells cytoplasm (Figure 11a). In ACR group, irregular air-blood barrier was observed that were formed of the irregular, swollen cytoplasm of PIs (Figure 11b). ACR+ASA group restored the barriers such that they appeared nearly like those of the controls (Figure 11c).

Light microscopic examination of lung tissue at $21^{\text {st }}$ postnatal day (PND 21)

\section{$H \& E$ stained sections}

On PND 21, H\&E stained sections from the lungs of control rat's offspring and those administrated ASA were nearly of the same appearance; control rats showed normal spongy structures in the form of alveoli separated by thin septa and alveolar sacs. Many relatively thin secondary septa could be detected (Figure 12). In contrast, the lung tissues of ACR group exhibited inter-alveolar septa with focal thickening and variable-sized alveoli. Dilated, congested blood vessels with heavy inflammatory mononuclear cell infiltration were also observed (Figure 13a). Large alveoli and dilated congested blood vessel (BV) with thick wall are noticed (Figure 13b). However, in the lung tissues of ACR+ASA group, alveoli are nearly of normal architecture, variable sized alveolar sacs and inter-alveolar septa of variable thickness were observed (Figure 14).

\section{Toluidine blue-stained sections of lung tissue at $21^{\text {st }}$ postnatal day (PND 21)}

In the lung tissues of control rat offspring and those administrated ASA had nearly the same appearance; control rats showed alveoli appeared to be lined with PIIs with rounded nuclei, while other cells had flat nuclei. The primary inter-alveolar septa appeared thin with fewer cells at the tips; some cells had pale nuclei, while others had flat nuclei. The secondary septa were composed of groups of 
cells; some of them had rounded nuclei, whereas others had flat nuclei at their tips. Blood capillaries could be seen facing the alveolar lumens (Figure 15). Compared to the control rat offspring, the lung tissue of ACR group revealed apparent increases in PIIs and noticeable thickening of the primary inter-alveolar septa (with many interstitial cells of variable shapes), with persistence of a double capillary network. There was mononuclear cells most probably macrophages (Figure 16). In the lung tissues of the ACR+ASA group, the inter-alveolar septa were apparently thinner than those in the lungs of the ACR- rat offspring. The secondary septa were thin with a single blood capillary facing the alveolar lumen; some thick septa persisted that were composed of groups of cells. (Figure 17).

\section{Electron microscopic examination of lung tissue at $21^{\text {st }}$ postnatal day (PND 21)}

Ultrathin sections from the lung tissues of control rat's offspring and those administrated ASA had nearly the same appearance; control rats showed normal inter-alveolar septa, as revealed by the presence of few interstitial cells along with a single capillary layer on one side. PIIs with euchromatic nuclei were detected bulging into the alveolar lumens (Figure 18). In the ACR group, the inter-alveolar septa were still thick with many interstitial cells, some of which had euchromatic nuclei, while others showed apoptotic nuclei. Accumulated collagen fibers were also observed (Figure 19a). The PIIs had irregular euchromatic nuclei and damaged irregular lamellar bodies (Figure 19b). A mononuclear cell most probably large macrophage with irregular shrunken nucleus, pseudopodia and many lysosomes could be seen (Figure 19c). In the ACR+ASA group, the inter-alveolar septa were thinner than those in the ACR group, and apparently fewer collagen fibers were observed (Figure 20a). Noticeable restoration of PII structures was present; the restored cells had euchromatic nuclei with full lamellar bodies, and microvilli (Figure 20b).

In the control rat offspring; the air--blood barriers were composed of attenuated PI cytoplasm, fused basal laminae and capillary endothelial cell cytoplasm (Figure 21a). In the ACR group, there was slight swelling of the cytoplasm in the PIs (Figure 21b), but in the ACR+ASA group, the PIs had regained their normal appearance (Figure 21c).

\section{Morphometric results}

No significant change in thickness of inter-alveolar septa in control rat's offspring compared with those administrated ASA.

Maternal ACR administration during gestation and lactation significantly increase the inter-alveolar thickness in the lungs of offspring at both PND 2 and PND 21 compared to their control group $(P<.05)$. However, in ACR+ ASA group the lungs exhibited a significant reduction of the inter-alveolar thickness at both PND 2 and PND 21 than those of their ACR group $(P<.05)$ (Figure 22).
Table 1: Effect of maternal ACR exposure and ACR+ASA exposure on serum endocan, MDA, and GSH in offspring lung tissue at PND 2

\begin{tabular}{ccccc}
\hline \multirow{2}{*}{ PND 2 } & \multicolumn{4}{c}{ Groups } \\
\cline { 2 - 5 } & $\begin{array}{c}\text { Negative } \\
\text { control }\end{array}$ & $\begin{array}{c}\text { Positive } \\
\text { control }\end{array}$ & ACR & ACR+ASA \\
\hline $\begin{array}{c}\text { Endocan } \\
\text { (ng/dL) }\end{array}$ & $0.22 \pm 0.03$ & $0.20 \pm 0.04$ & $0.81 \pm 0.08^{\mathrm{ab}}$ & $0.42 \pm 0.07^{\mathrm{abc}}$ \\
$\begin{array}{c}\text { MDA } \\
(\mathrm{nmol} / \mathrm{g} . \text { tissue })\end{array}$ & $29 \pm 1.3$ & $30.03 \pm 0.9$ & $59.9 \pm 1.03^{\mathrm{ab}}$ & $40.5 \pm 0.7^{\mathrm{abc}}$ \\
$\begin{array}{c}\text { GSH } \\
\text { (mg/g. tissue) }\end{array}$ & $40.5 \pm 4.5$ & $43.1 \pm 4.8$ & $19.5 \pm 0.9^{\mathrm{ab}}$ & $28.6 \pm 2.8^{\mathrm{abc}}$ \\
\hline
\end{tabular}

All values are expressed as mean $\pm \mathrm{SD}, \mathrm{n}=10$. a significant vs negative control group, $\mathrm{b}$ significant vs positive control, c significant vs ACR $(P<.05)$. A one-way ANOVA followed by post hoc Tukey test multiple comparisons between groups.

PND, postnatal date; ACR, acrylamide; ASC, ascorbic acid; MDA, malondialdehyde; GSH, reduced glutathione

Table 2: Effect of maternal ACR exposure and ACR+ASA exposure on serum endocan, MDA, and GSH in offspring lung tissue at PND 21

\begin{tabular}{ccccc}
\hline \multirow{2}{*}{ PND 2 } & \multicolumn{4}{c}{ Groups } \\
\cline { 2 - 5 } & $\begin{array}{c}\text { Negative } \\
\text { control }\end{array}$ & $\begin{array}{c}\text { Positive } \\
\text { control }\end{array}$ & ACR & ACR+ASA \\
\hline $\begin{array}{c}\text { Endocan } \\
\text { (ng/dL) }\end{array}$ & $0.24 \pm 0.05$ & $0.21 \pm 0.06$ & $0.96 \pm 0.2^{\mathrm{ab}}$ & $0.45 \pm 0.03^{\mathrm{abc}}$ \\
$\begin{array}{c}\text { MDA } \\
(\mathrm{nmol} / \mathrm{g} . \text { tissue) }\end{array}$ & $28.7 \pm 2.7$ & $30.8 \pm 4.5$ & $70.5 \pm 2.9^{\mathrm{ab}}$ & $53.8 \pm 3.1^{\mathrm{abc}}$ \\
$\begin{array}{c}\text { GSH } \\
(\mathrm{mg} / \mathrm{g} . \text { tissue })\end{array}$ & $40.5 \pm 4.5$ & $43.1 \pm 4.8$ & $19.5 \pm 0.9^{\mathrm{ab}}$ & $28.6 \pm 2.8^{\mathrm{abc}}$ \\
\hline All values are & & & & \\
\hline
\end{tabular}

All values are expressed as mean $\pm S D, n=10$ (but $n=7$ in $A C R$ group). a significant vs negative control group, b significant vs positive control, c significant vs ACR $(P<.05)$. A one-way ANOVA followed by post hoc Tukey test multiple comparisons between groups.

PND, postnatal date; ACR, acrylamide; ASC, ascorbic acid; MDA, malondialdehyde; GSH, reduced glutathione

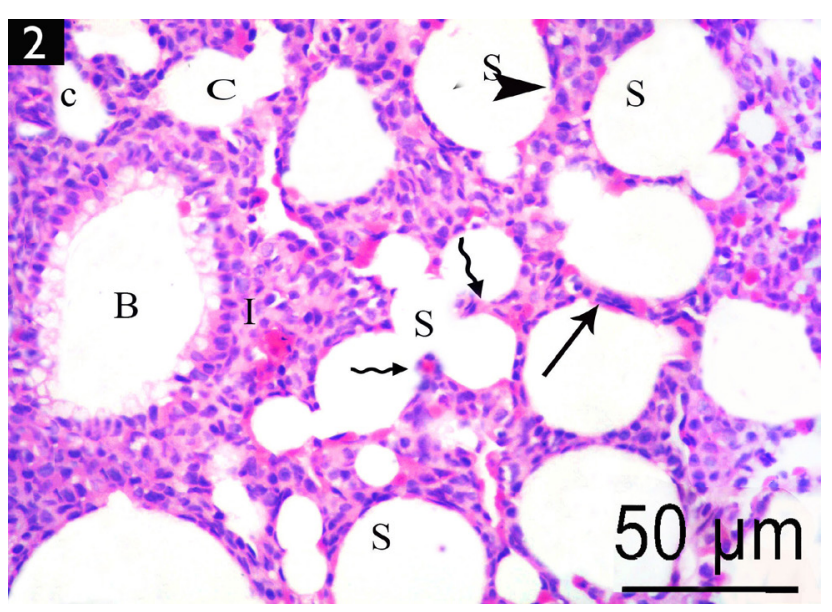

Fig. 2: Photomicrograph of lung sections of control groups at $2^{\text {nd }}$ PND showing bronchial passage (B), alveolar channels (C) and saccules (S) separated by primary septa of variable thickness; thin septa (arrow) and thicker septa (arrowhead). Relatively few thick secondary septa (wavy arrow) are projecting into the saccular lumens (S). H\&E x400. 


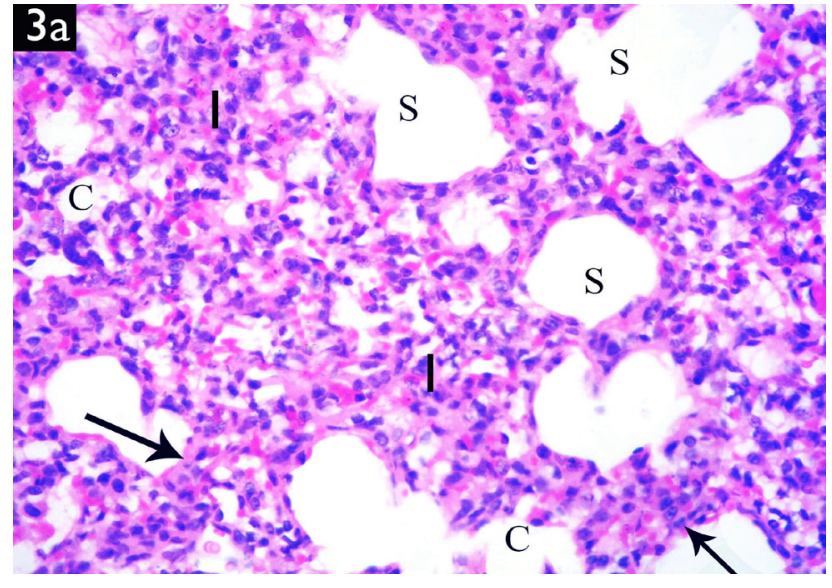

Fig. 3a: Photomicrograph of lung sections of ACR group at $2^{\text {nd }}$ PND showing highly cellular (I) and relatively thick primary septa (arrow). Saccules (S) and alveolar channels (C) can be seen. $\mathrm{H} \& \mathrm{E}$ x400.

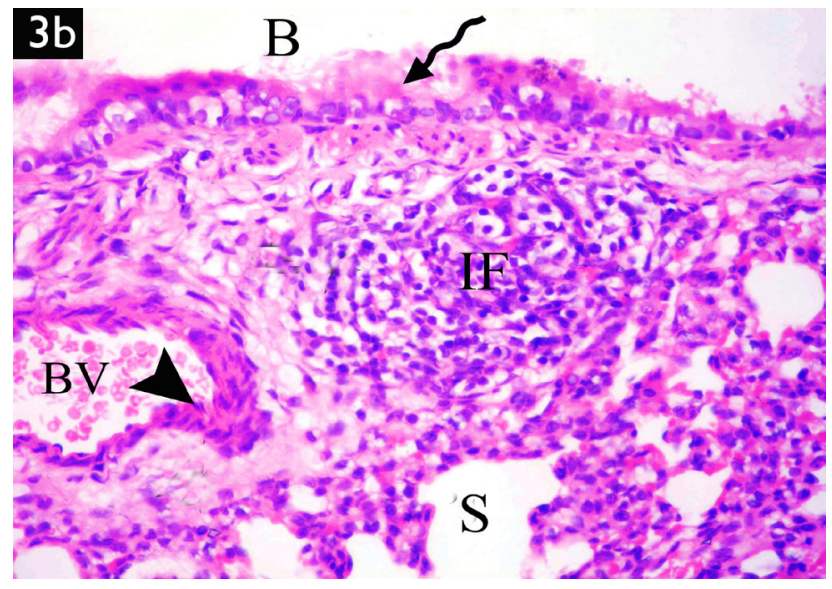

Fig. 3b: Photomicrograph of lung sections of ACR group at $2^{\text {nd }}$ PND showing bronchus (B) with hyperplastic epithelium (wavy arrow) and focal infiltration (IF). Dilated, congested blood vessel (Bv) with irregular lumen (arrow head) and saccules (S) are also seen. H\&E $x 400$.

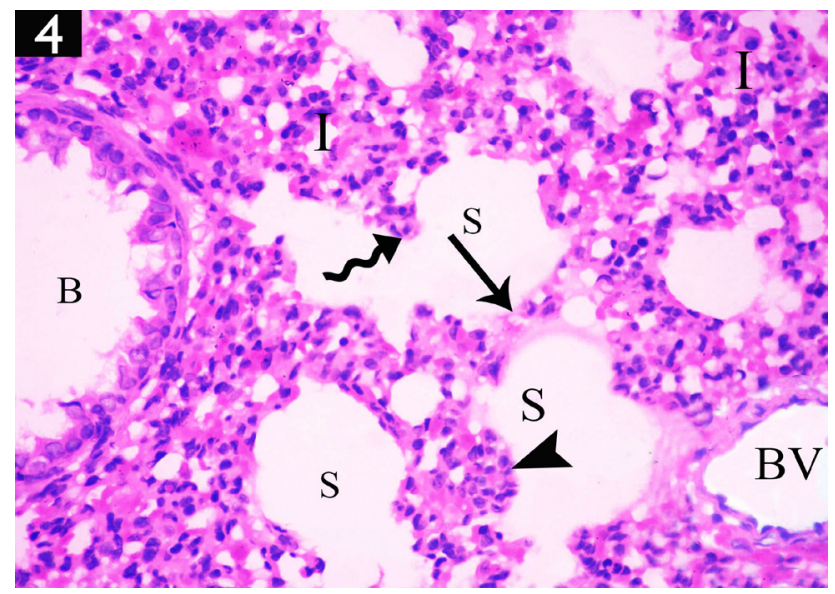

Fig. 4: Photomicrograph of lung sections of ACR +ASA group at ${ }^{2 n d}$ PND showing variable-sized saccules (S), separated by apparently less cellular (I) primary septa (arrowhead) than those of ACR- group. Apparently normal bronchial passage (B), and normal blood vessels (Bv) are seen. Small secondary septa can also be observed (wavy arrow). H\&E x400.

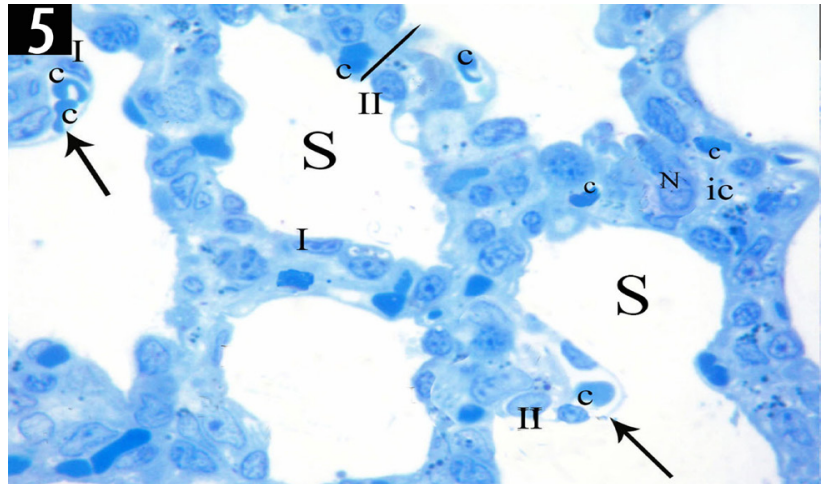

Fig. 5: Photomicrograph of lung sections of control groups at $2^{\text {nd }}$ PND showing group of interstitial cells (ic); some of these cells have large pale nuclei (N), while other cells have flat nuclei (I). The primitive air spaces (S) are lined with cells having large pale nuclei (II). Blood capillaries (c) can be seen on both sides of the primary septa (line). Thick secondary septa (arrow) are bulging in the lumen with blood capillaries (c) at their tips. Toluidine blue $\times 1000$

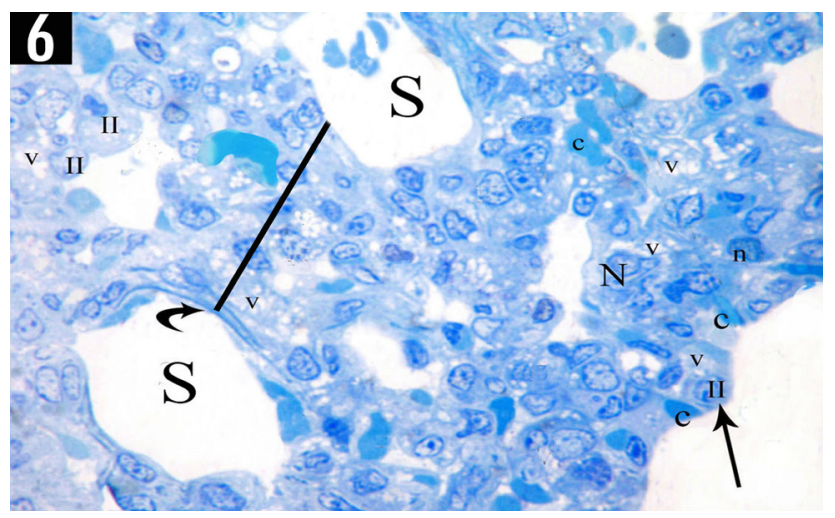

Fig. 6: Photomicrograph of lung sections of ACR group at $2^{\text {nd }}$ PND showing markedly thickened primary inter-alveolar septa (line) with a large number of differently shaped interstitial cells (n). The saccular walls (S) are lined with cells with rounded nuclei $(\mathrm{N})$ and vacuolated cytoplasm $(\mathrm{V})$. Short, thick secondary septa (arrow) are composed of blood capillaries (c) and round cells (II) with vacuolated cytoplasm (V). Fine collagen fibres can be observed in the wall of the saccule (curved arrow) Toluidine blue $\times 1000$

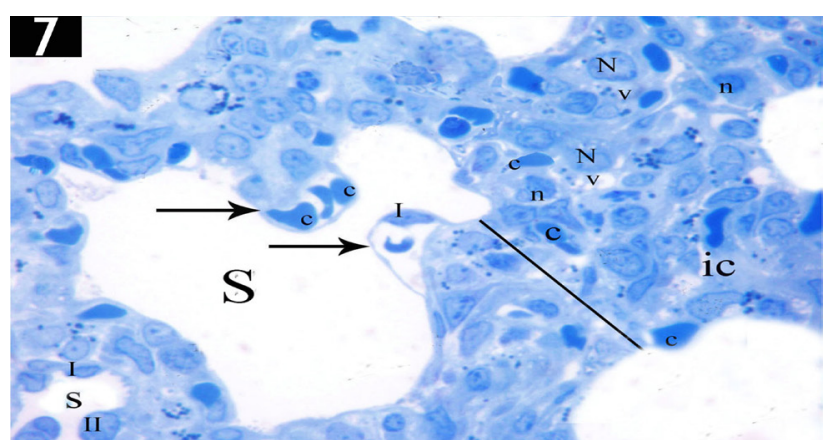

Fig. 7: Photomicrograph of lung sections of ACR +ASA group at $2^{\text {nd }}$ PND showing that the primary septa (line) having fewer interstitial cells (ic) compared with that of ACR group; some of the interstitial cells have large pale nuclei $(\mathrm{N})$ with cytoplasmic vacuoles (v) whereas others have dark nuclei (n), saccules (S) are lined with cells with large pale nuclei (II) while other cell have flat nuclei (I). Many thick secondary septa (arrow) with double capillary layer $(\mathrm{C})$ can be seen. Toluidine blue $\times 1000$ 


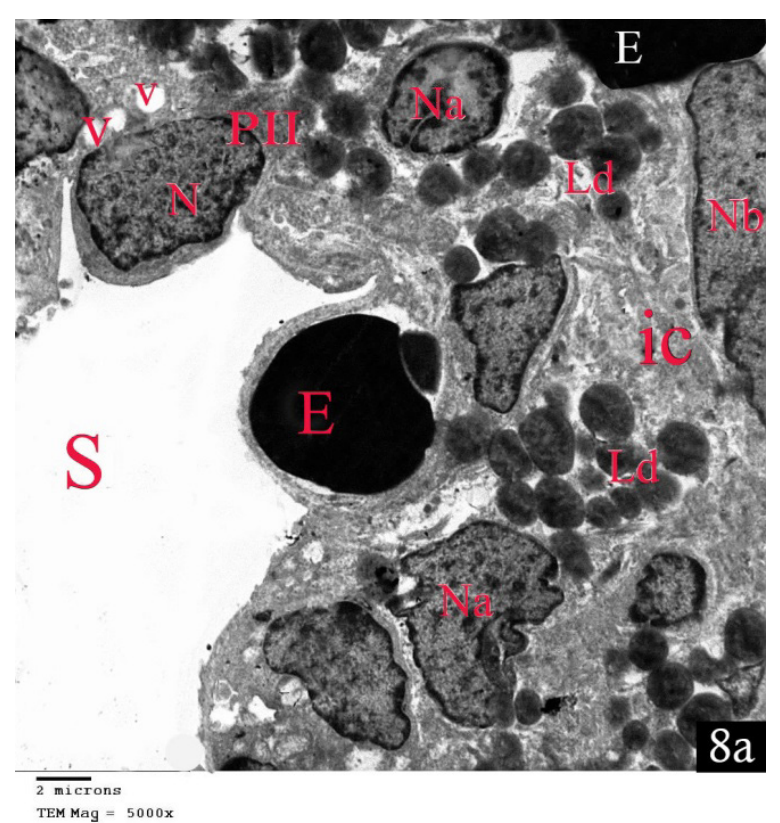

Fig. 8a: Transmission electron micrograph of lung sections in control groups at $2^{\text {nd }}$ PND showing double capillary layer present (E) of saccular wall (S), group of interstitial cells (ic) are observed; some of them have large rounded euchromatic nuclei $(\mathrm{Na})$ with lipid droplets in the cytoplasm (Ld), whereas others have elongated nuclei $(\mathrm{Nb})$ without lipid droplets in the cytoplasm. Pneumocyte type II (PII) has euchromatic nuclei (N) and empty lamellar bodies "vacuoles" (v). TEM a, $\times 5000$

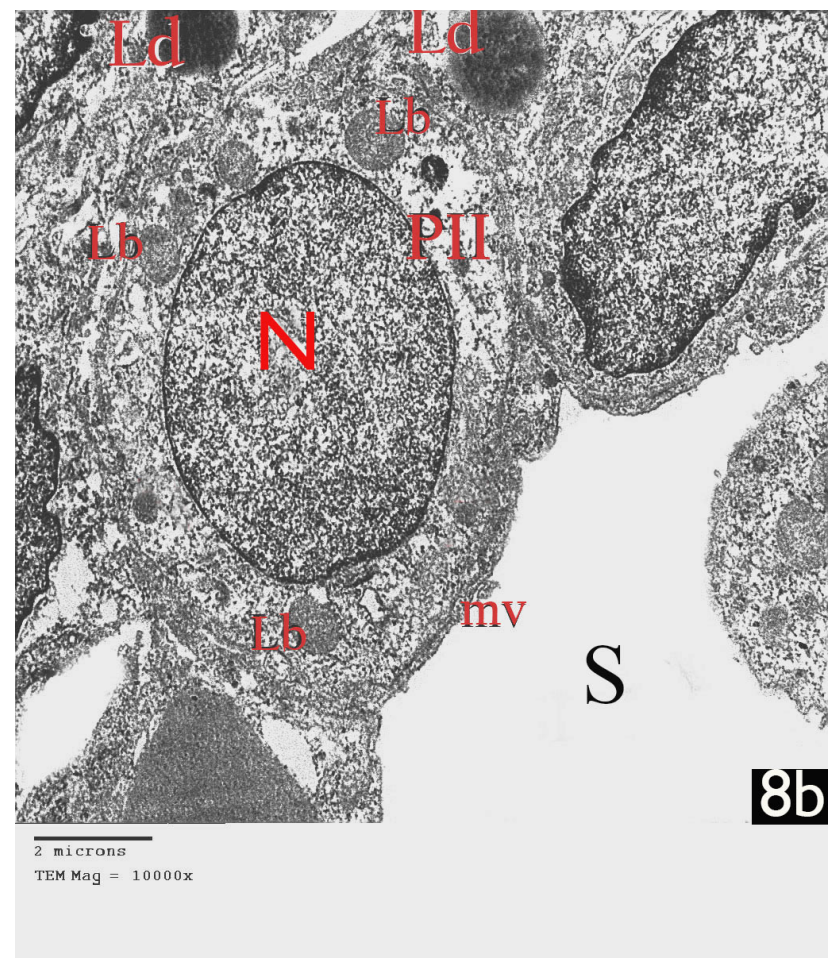

Fig. 8b: Transmission electron micrograph of lung sections in control groups at $2^{\text {nd }}$ PND showing pneumocyte type II (PII) has few apical microvilli (mv) has large euchromatic nuclei (N) bulging into the saccular lumen (S) with full lamellar bodies (Lb) and Lipid droplets can be seen (Ld). TEM b, $\times 10000$.

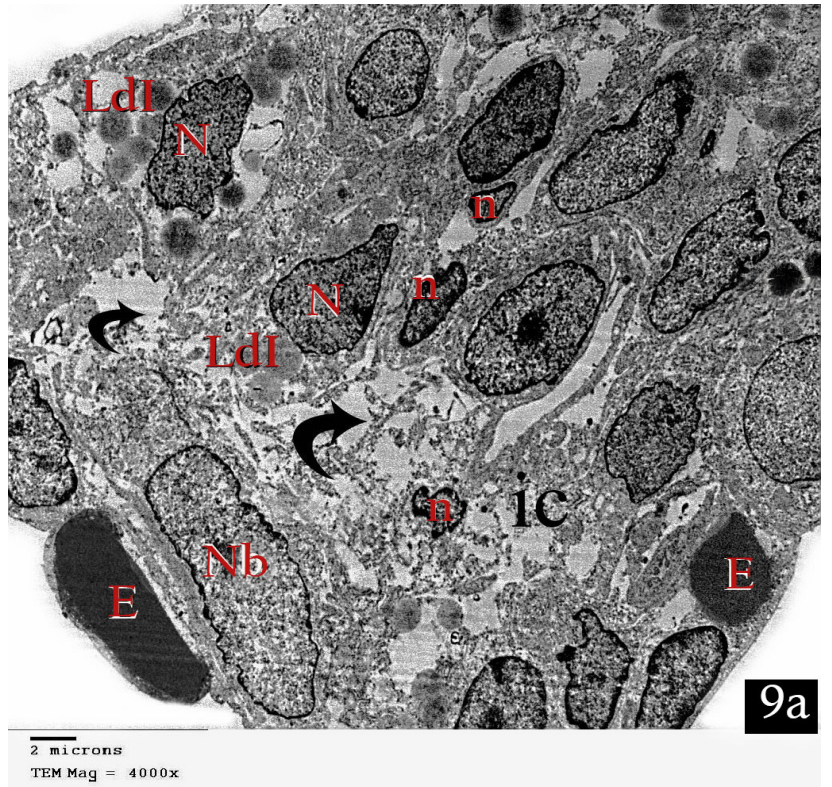

Fig. 9a: Transmission electron micrograph of lung sections in ACR group at $2^{\text {nd }}$ PND showing thick saccular wall with double capillary layer (E) and many interstitial cells (ic); some have heterochromatic nuclei $(\mathrm{N})$ with few pale lipid droplets (LdI), others irregular and shrunken nuclei (n) and some have flat nuclei $(\mathrm{Nb})$. Electron-lucent vacuolated areas can be seen (curved arrow). TEM a $\times 4000$

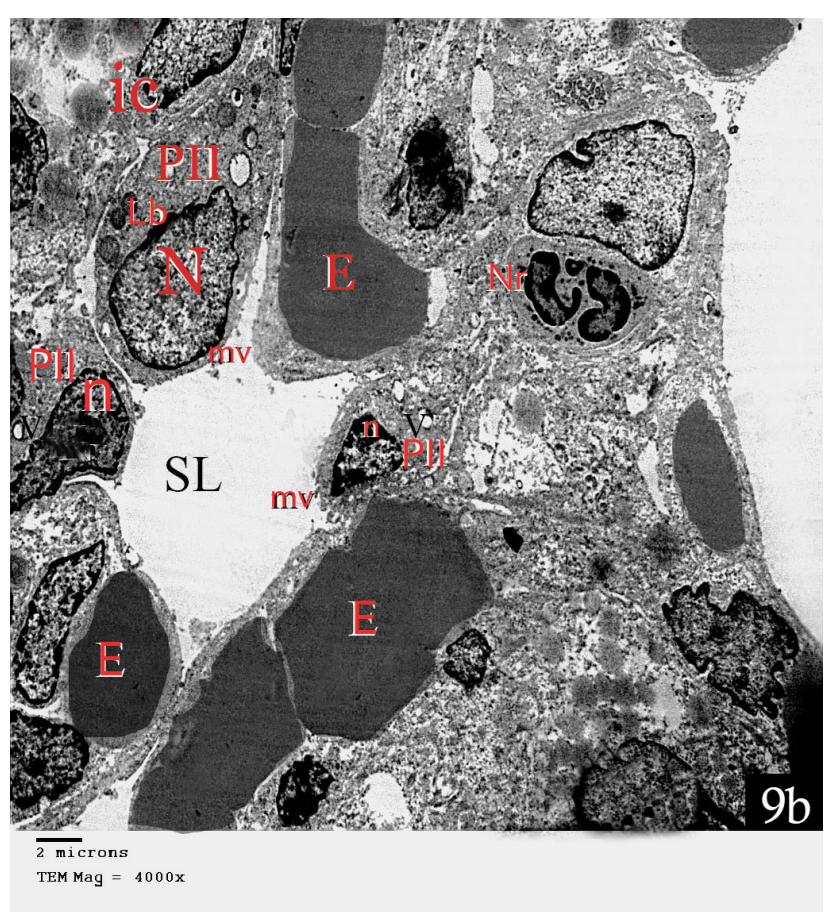

Fig. 9b: Transmission electron micrograph of lung sections in ACR group at $2^{\text {nd }}$ PND showing many types II pneumocytes (PII); some of them have large euchromatic nuclei $(\mathrm{N})$ with apical microvilli (mv), others have heterochromatic nuclei (n) mononuclear cell most probably Neutrophilis $(\mathrm{Nr})$ can be observed. Many blood vessels (E), saccular lumen (SL) and interstitial cells (ic) still be seen. TEM $b \times 4000$. 


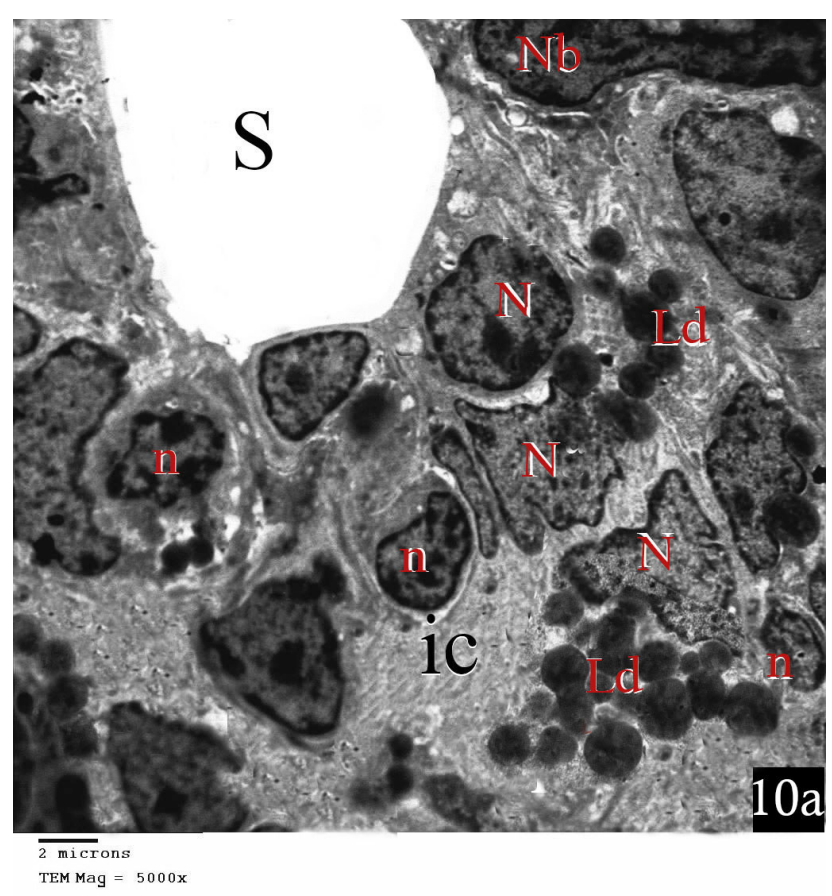

Fig. 10a: Transmission electron micrograph of lung sections in ACR +ASA group at $2^{\text {nd }}$ PND showing few interstitial cells (ic) with variable shaped nuclei; some of them have large rounded euchromatic nuclei $(\mathrm{N})$ with lipid droplets in the cytoplasm $(\mathrm{Ld})$, whereas others have apparently shrunken nuclei (n). Other cells have elongated nuclei $(\mathrm{Nb})$ without lipid droplets in their cytoplasm can be observed. Saccular lumen (S) still be seen. TEM a, $\times 5000$

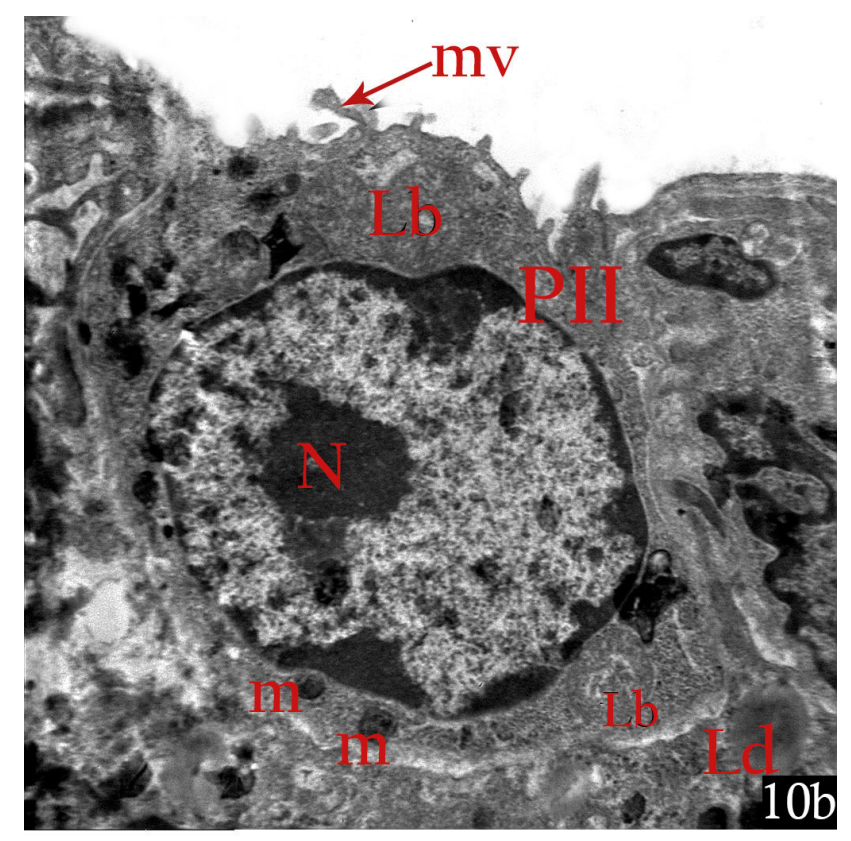

$\overline{500 \mathrm{~nm}}$

TEM Mag $=15000 \mathrm{x}$

Fig. 10b: Transmission electron micrograph of lung sections in ACR +ASA group at $2^{\text {nd }}$ PND (PII) has large euchromatic nucleus $(\mathrm{N})$, lamellar bodies $(\mathrm{Lb})$, mitochondria $(\mathrm{m})$ and apical microvilli (mv). Lipid droplet can also be seen (Ld). TEM b, $\times 15000$.
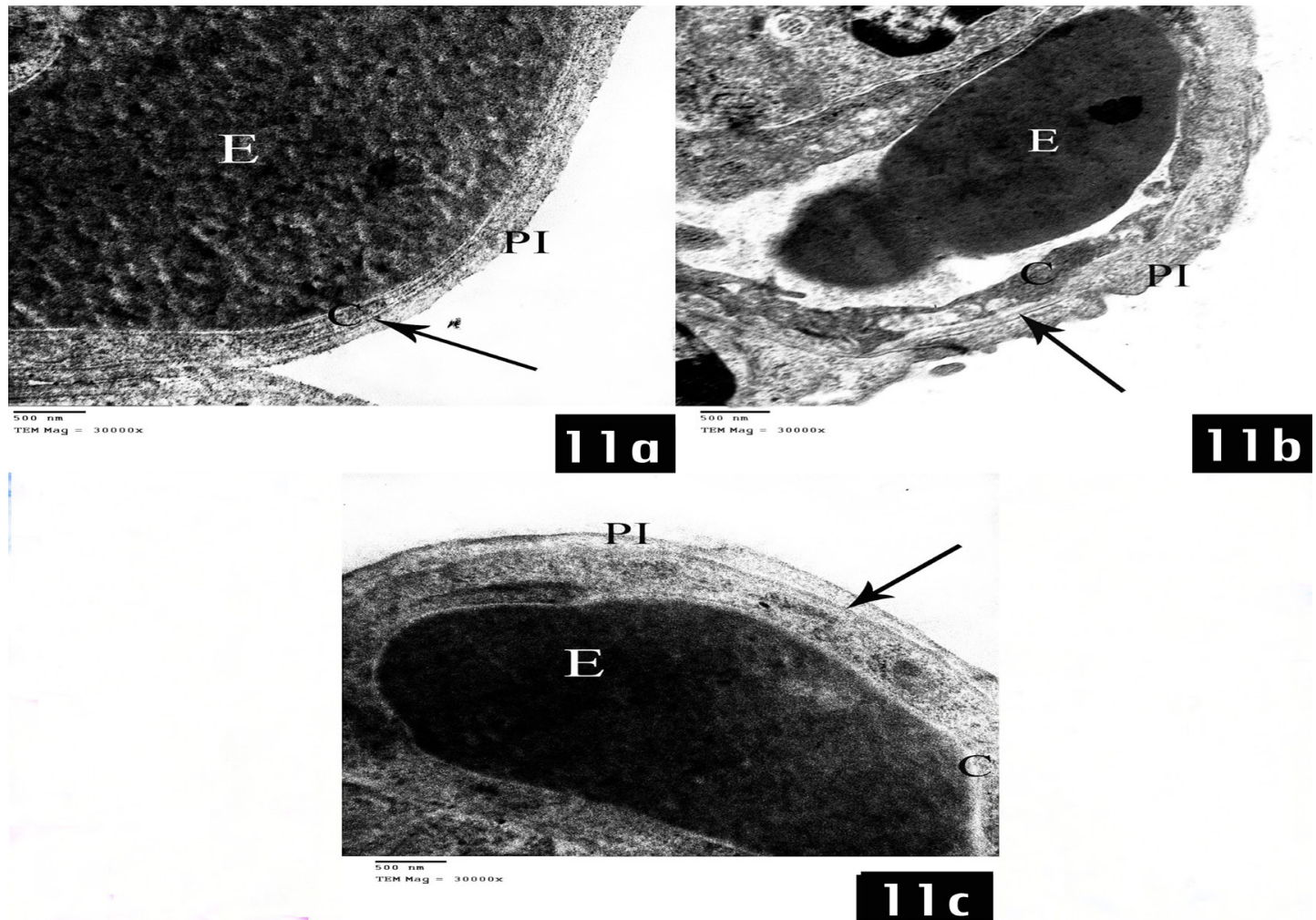

Fig. 11: Transmission electron micrographs of lung sectionsin different experimental groups at $2^{\text {nd }}$ PND a) Control rat offspring; the air-blood barrier formed of the attenuated pneumocytes type I cytoplasm (PI), fused basal laminae (arrow), and cytoplasm of capillary endothelial cells (E). b) ACR-group, irregular air-blood barrier has irregular swollen cytoplasm of pneumocytes type I (PI). c) ACR +ASA group, the air-blood barrier is nearly normal. TEM.a, b, $\mathrm{c} \times 30,000$ 


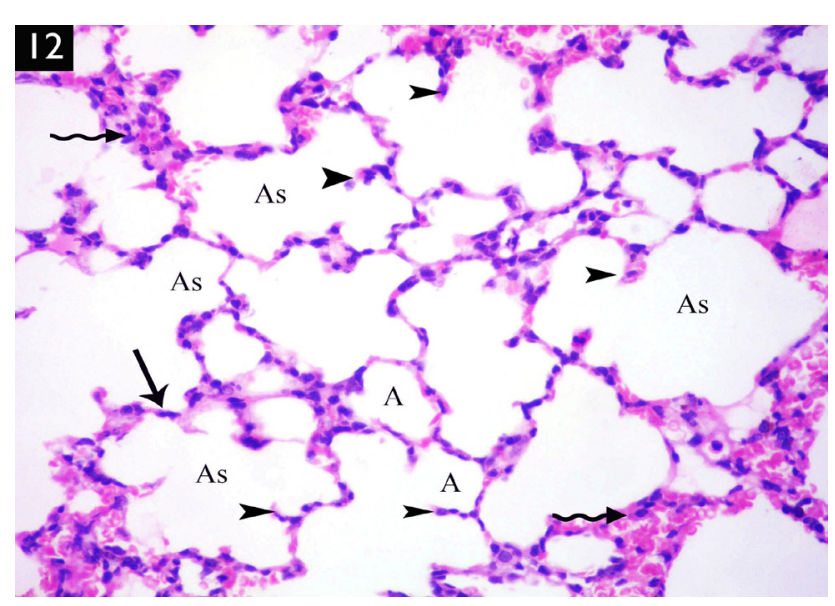

Fig. 12: Photomicrograph of lung sections of control groups at $21^{\text {st }}$ PND showing normal several alveoli (A), alveolar sacs (As) and many relatively thin secondary septa (arrow head) are visible. Inter-alveolar septa with variable thickness; some appear thin (arrow) while others appear thicker (wavy arrow) can be seen. H\&E x400.

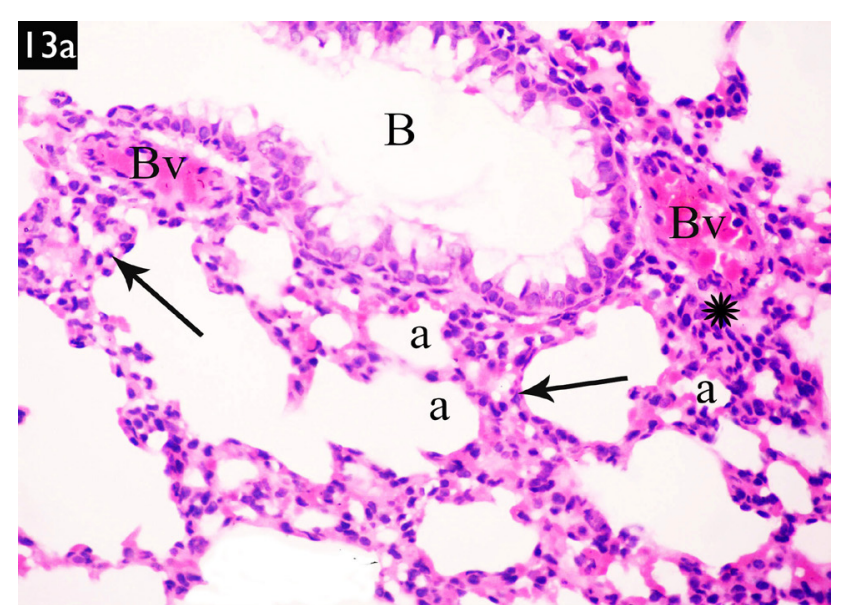

Fig. 13a: Photomicrograph of lung sections of ACR group at $21^{\text {st }}$ PND showing alveoli of variable sizes (a), bronchial passage (B), thickened septa (arrow) with heavy cellular infiltration $(*)$ and congested blood vessel (Bv) are also noticed. H\&E x400

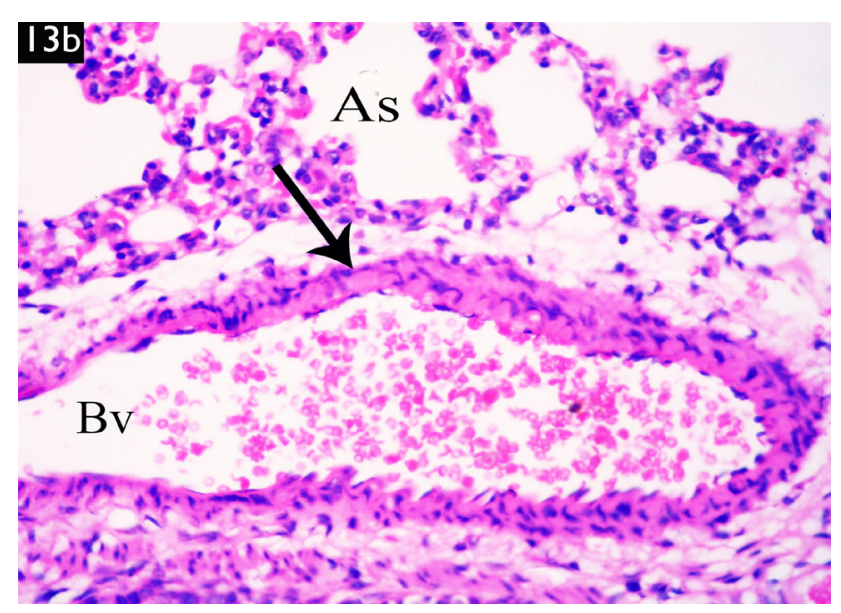

Fig. 13b: Photomicrograph of lung sections of ACR group at $21^{\text {st }}$ PND showing large alveoli, dilated congested blood vessel (BV) with thick wall (arrow) and Alveolar sacs (As ) can be also seen. H\&E x400.

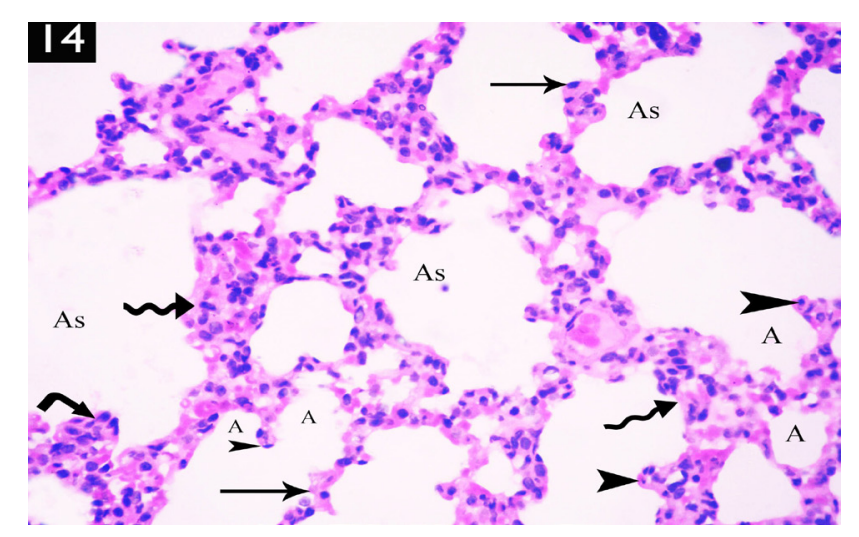

Fig. 14: Photomicrograph of lung sections of ACR $+A S A$ group at $21^{\text {st }}$ PND showing the alveoli (A) are nearly of normal architecture, several alveolar sacs (AS) and inter-alveolar septa of variable thickness some appear thin (arrow) while others appear thicker (wavy arrow). Secondary septa (arrow head) and apparently thicker septa (curved arrow) can be seen. . H\&E x400.

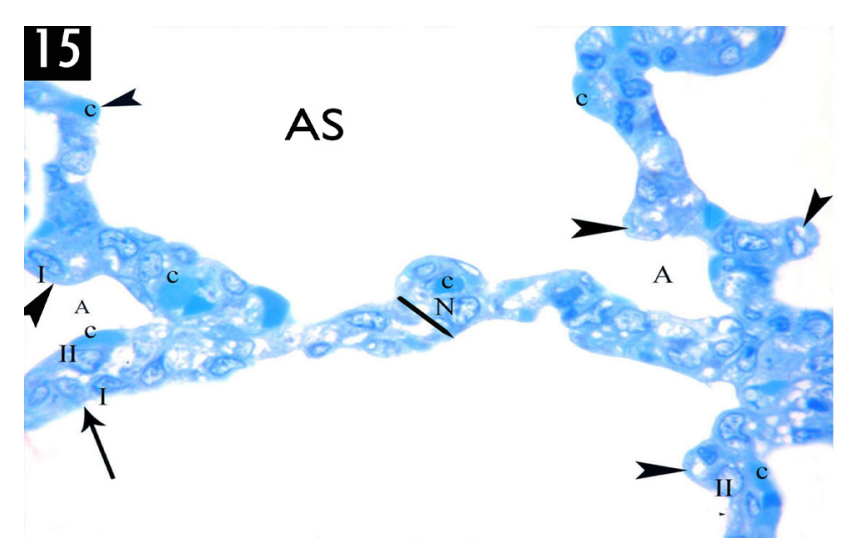

Fig. 15: Photomicrograph of lung sections of control groups at $21^{\text {st }}$ PND showing alveoli (A) lined by cell with rounded nuclei (II) and others with flat nuclei (I). Primary inter-alveolar septa (line) are thin formed of pale cell nuclei $(\mathrm{N})$. Secondary septa are composed of a group of cells (head arrows); some of them have rounded nuclei whereas others at their tips have flat nuclei. Blood capillaries (c) can be seen Toluidine blue $\times 1000$

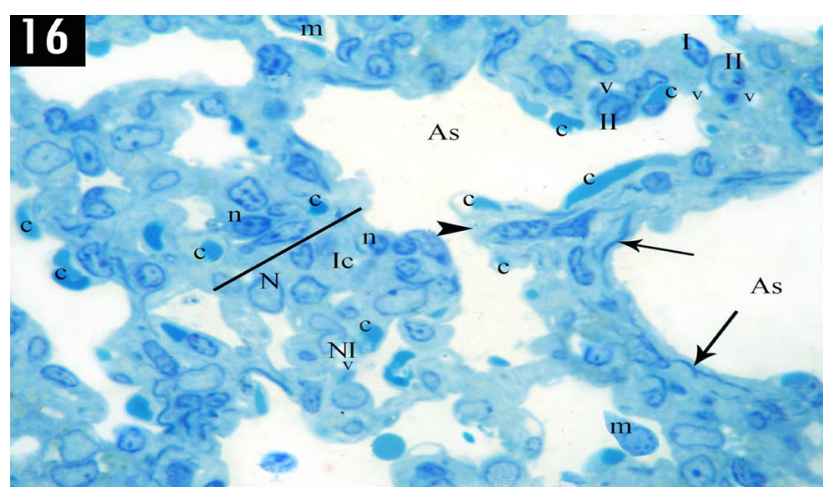

Fig. 16: Photomicrograph of lung sections of ACR- group at $21^{\text {st }}$ PND showing alveolar sac (AS) lined by cell with rounded nuclei (II) containing vacuoles within the cytoplasm (v) and others has flat nuclei (I). Thickened inter-alveolar septa (line) have polymorphic cells; some have pale nuclei $(\mathrm{N})$, some have pale kidney shaped nuclei (NI) and others have dark nuclei (n). Blood capillaries (c) on both sides of septa are seen, fine collagen fibers are noticed (arrow). Macrophage (m) still be seen. Thickened secondary septa with double capillary layer (head arrow) are seen. Toluidine blue $\times 1000$ 


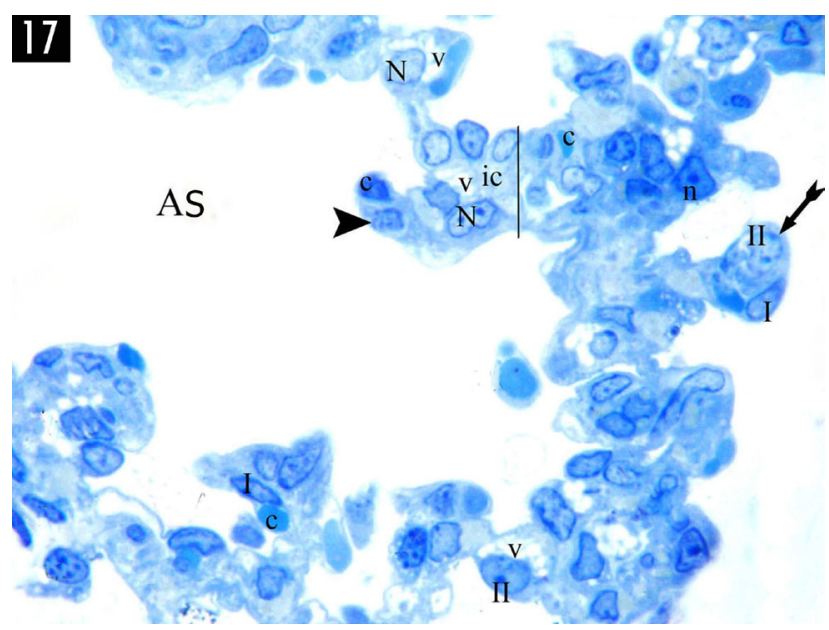

Fig. 17: Photomicrograph of lung sections of ACR +ASA group at $21^{\text {st }}$ PND showing the inter-alveolar septa (line) which appears apparently less cellular (ic) than those of ACR group with pale cell nuclei $(\mathrm{N})$ has vacuoles within its cytoplasm (v) and dark round nuclei (n). Some secondary septa (head arrow) are thin with single blood capillary (C) and other are apparently thick (bifid arrow). Alveolar sac (AS) lined by cell with rounded nuclei (II) and others with flat nuclei (I) is still noticed. Toluidine blue $\times 1000$

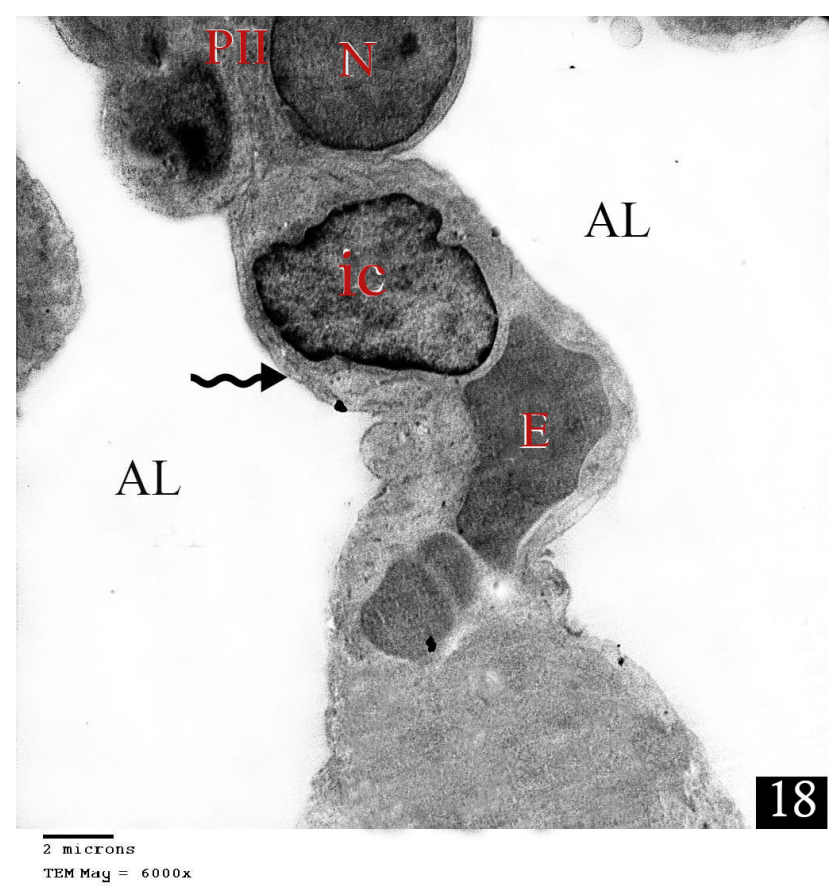

Fig. 18: Transmission electron micrograph of lung sections in control groups at $21^{\text {st }}$ PND showing the intera-alveolar septum (zigzag arrow) with pneumocyte type II (PII) has euchromatic nuclei $(\mathrm{N})$ bulging into the alveolar lumen (AL). Single capillary layer (E) and few interstitial cells can be seen in the alveolar septum (ic). TEM, $\times 6000$

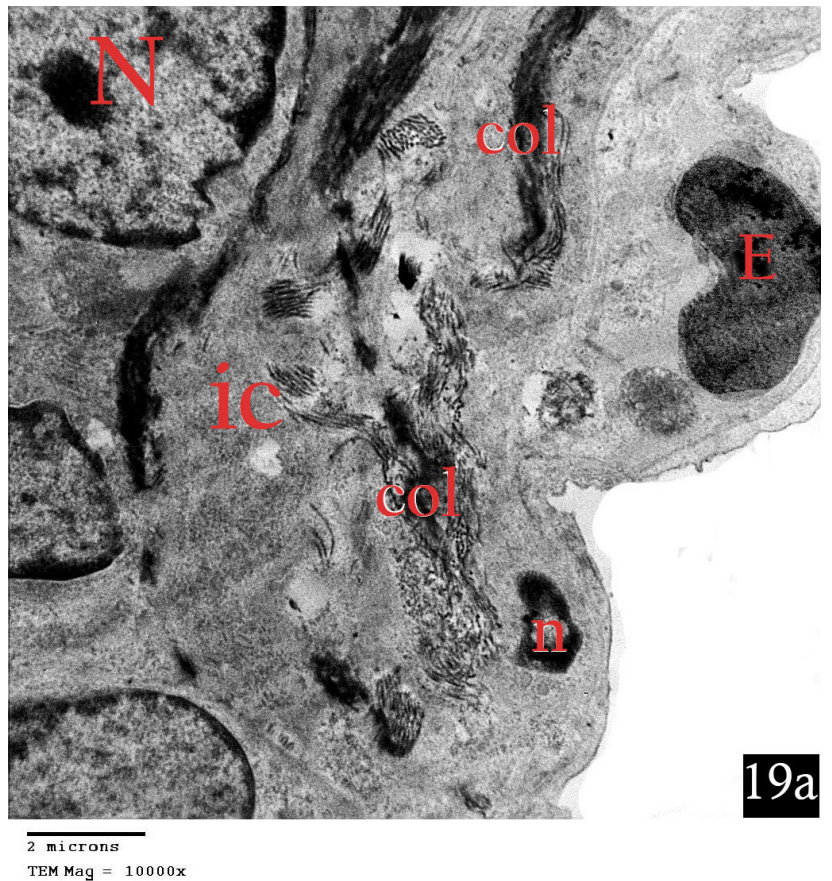

Fig. 19a: Transmission electron micrograph of lung sections in ACR-group at $21^{\text {st }}$ PND showing thick alveolar wall with many interstitial cells (ic); some have large euchromatic nuclei $(\mathrm{N})$ and others have shrunken nuclei (n). Accumulated collagen fibers (col) and blood capillaries (E) can be observed. TEM, a, $\times 10000$

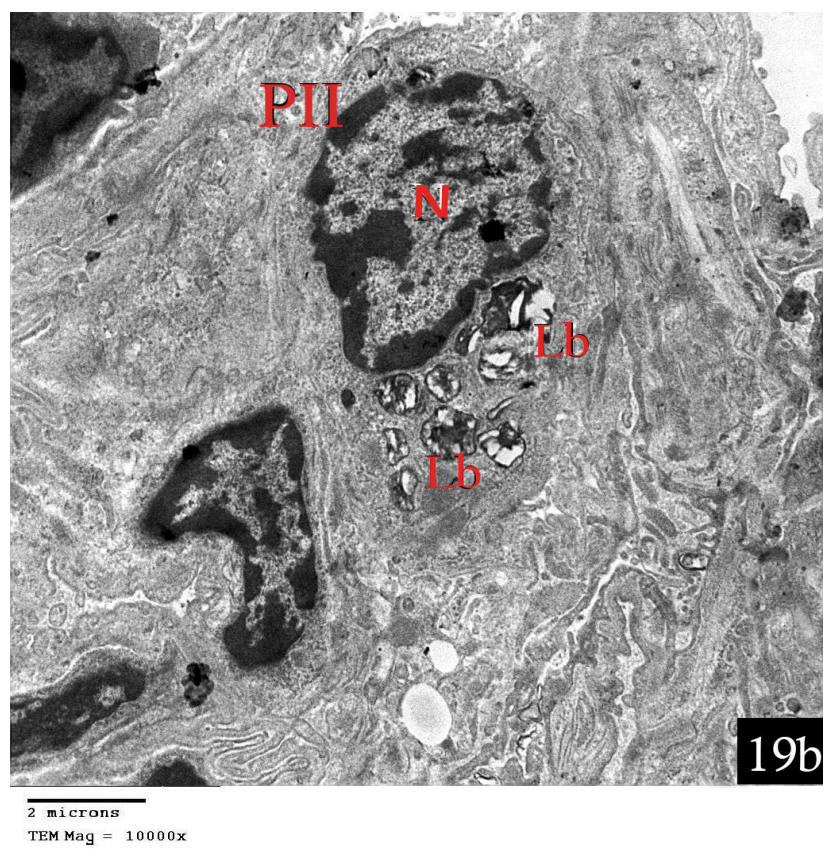

Fig. 19b: Transmission electron micrograph of lung sections in ACR- group at $21^{\text {st }}$ PND showing pneumocyte II (PII) have euchromatic nuclei $(\mathrm{N})$ and damaged, irregular lamellar bodies ( $\mathrm{Lb}(. \mathrm{TEMb} \times 10000$ 


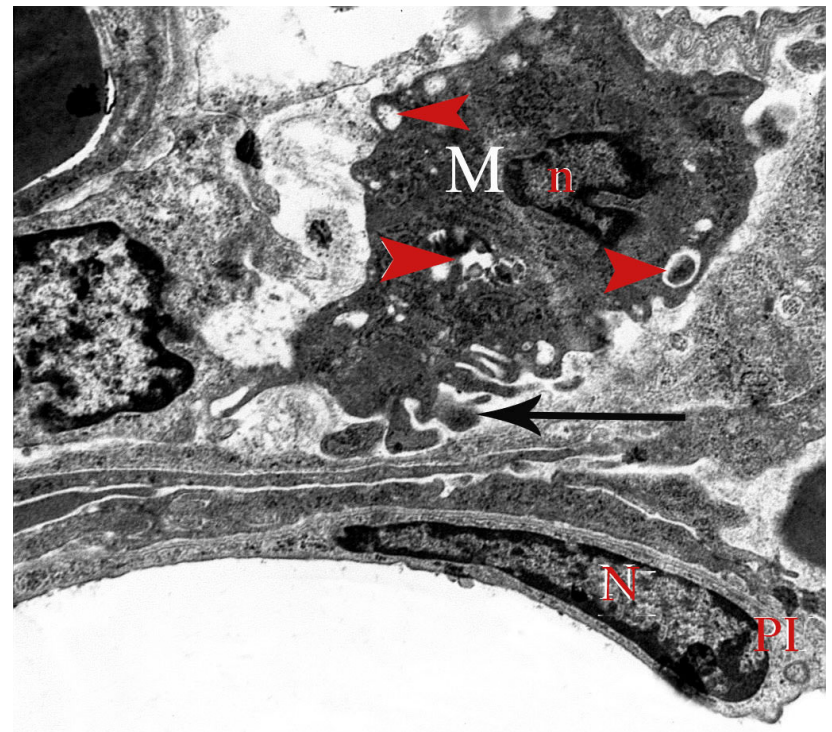

$19 c$

$\overline{500} \mathrm{~nm}$

TEM Mag $=15000 \mathrm{x}$

Fig. 19c: Transmission electron micrograph of lung sections in ACR-group at $21^{\text {st }}$ PND showing a large macrophage $(\mathrm{M})$ with irregular shrunken nucleus (n), pseudopodia (arrow), and many lysosomes (arrowheads). Pneumocyte I (PI) with flat nuclei (N) can also be seen. TEMc, $\times 15000$

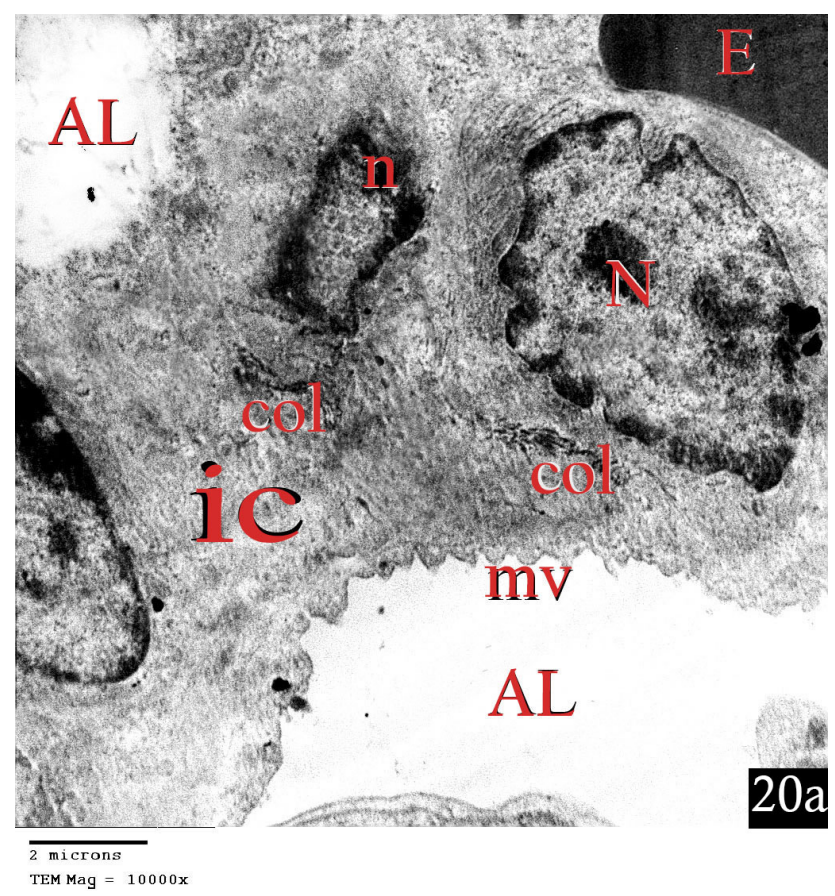

Fig. 20a: Transmission electron micrograph of lung sections in ACR+ASA group at $21^{\text {st }}$ PND showing apparently thin alveolar wall with few interstitial cells (ic); some have euochromatic nuclei (N) and others have irregular shrunken nuclei (n). Apparently fewer collagen fibers (col) than those of ACR group are visible. Microvilli (mv) are projecting into the alveolar lumen (AL), blood capillaries are also visible (E). TEM, a $\times 10000$

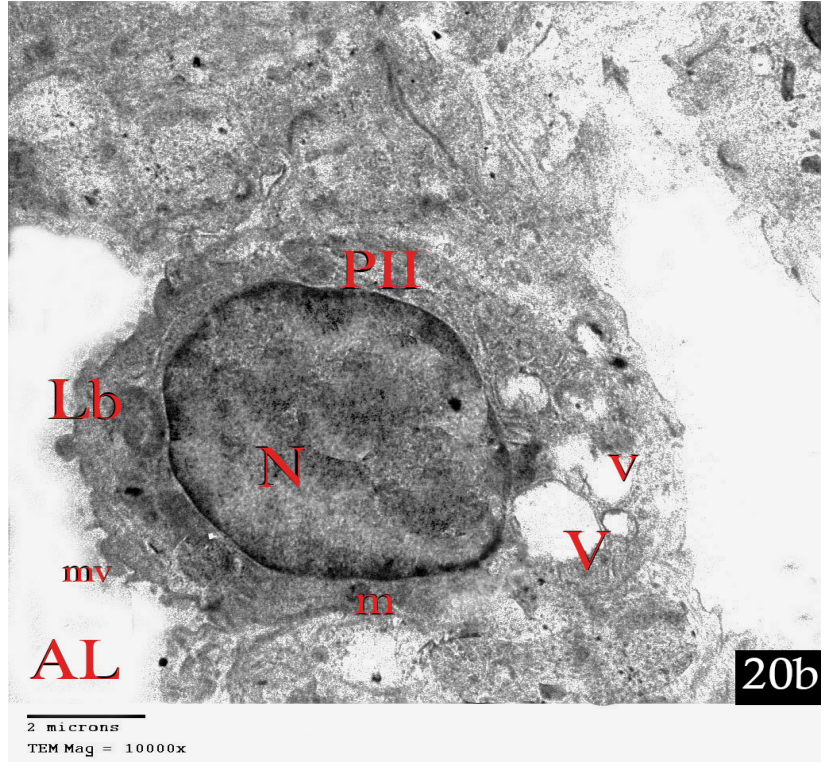

Fig. 20b: Transmission electron micrograph of lung sections in ACR+ASA group at $21^{\text {st }}$ PND showing pneumocyte II (PII) with microvilli (mv) and has euchromatic nucleus $(\mathrm{N})$ in addition to full lamellar bodies (Lb). Some large vacuolated empty lamellar bodies (V) and mitochondria (m) are also noticed. TEM, b, $\times$ 10000
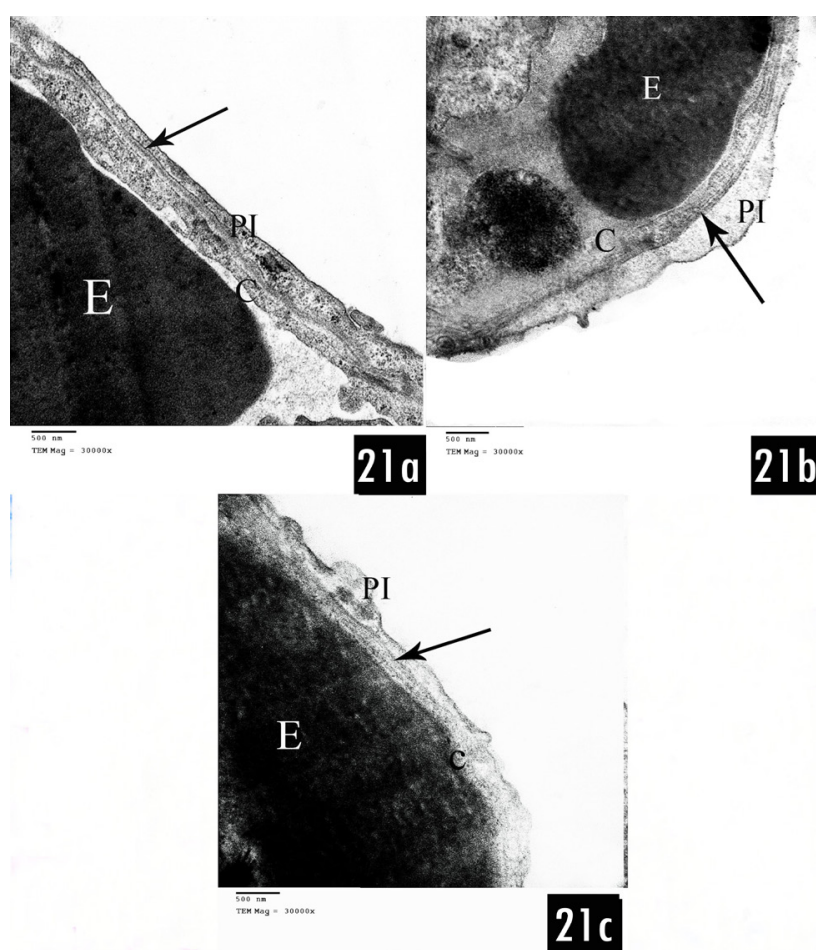

Fig. 21: Transmission electron micrographs of lung sections in different experimental groups at $21^{\text {st }}$ PND showing a) Control group; the air-blood barrier is formed by attenuated pneumocyte I (PI) cytoplasm, fused basal laminae (arrow), and cytoplasm (c) of capillary endothelial cells (E). b) ACR-group; air-blood barrier with irregular, swollen cytoplasm of both pneumocyte I (PI) and capillary endothelial cells (c) and thickened, irregular fused basal laminae (arrows) can be clearly seen. c) ACR +ASA group; the air-blood barrier showing slightly swollen cytoplasm of both pneumocyte I (PI) and capillary endothelial cells (C) which is less than that of ACR-exposure. TEM.a, b, $c \times 30,000$ 


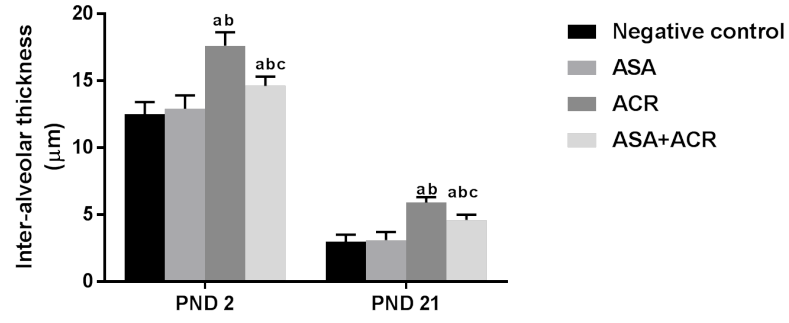

Fig. 22: Effect of acrylamide and ascorbic acid on inter-alveolar thickness at PND 2 and PND 21 .All values are expressed as mean $\pm S D, n=10$ (but $n=7$ in ACR group PND 21). a significant vs negative control group, $\mathrm{b}$ significant vs positive control, c significant vs ACR $(P<.001)$. A one-way ANOVA followed by post hoc Tukey test multiple comparisons between groups.

\section{DISCUSSION}

ACR exposure has recently been stated to be a potential risk factor from early development until ageing ${ }^{[29]}$. There is a vast amount of literature on the mutagenic and carcinogenic effects of ACR; however, there are very few data on ACR-induced morphological changes during the embryonic and postnatal development of different organs. Therefore, the present study was designed to investigate up the effect of perinatal ACR exposure on lung development in albino rats and to examine the possible protective role of ASA against ACR toxicity. We selected PND 2 and PND 21 as the time points because; PND 2 represents the saccular stage of lung development, while PND 21 represents the alveolar stage ${ }^{[30]}$.

ACR and its metabolic products can pass through the placenta and breast milk of lactating mothers to distribute to almost all tissues of the fetus and, exert toxic effects ${ }^{[31]}$.

In this study, light microscopic examination of the control lungs at $2^{\text {nd }}$ day showed normal histological patterns; the lungs were; composed of smooth, outlined saccules separated by thick primary septa and short, thick secondary septa. These findings were confirmed by electron microscopic examination, which showed the presence of many layers of interstitial cells with different shapes and double capillary layers in both septa. Some investigators reported similar findings ${ }^{[32]}$. Moreover, PIIs were observed with rounded, euchromatic nuclei and vacuolated cytoplasm in addition to many lamellar bodies. Some scientists stated that there are two types of interstitial cells detected on PND 2, both of which have the same embryonic origin: 1) lipofibroblast interstitial cells (LICs) with irregular nuclei and many lipid droplets and 2) myofibroblasts or non -lipofibroblasts (non -LICs) with irregular nuclei and a lack of lipid droplets ${ }^{[33]}$. Another study suggested that the LICs may play an important role in septa and alveolar development ${ }^{[34]}$. There was evidence that non -LICs play roles in and collagen fibers formation, which is involved in secondary septa formation ${ }^{[35]}$.

In contrast, light microscopic examination of ACR group at the same time period showed marked thickening of the primary septa in comparison with the control group.
This thickening was assured with morphometric results. Electron microscopic examination, revealed the presence of differently shaped interstitial cells; some of them had apparently shrunken nuclei arranged in many layers. Such increase in thickening was attributed to increased deposition of collagen fibers and marked cellular infiltration ${ }^{[36]}$. Additionally, vascular congestion and cellular infiltration were observed, which could be explained by changes in the integrity of the lung vessels and increased capillary permeability ${ }^{[37]}$. Electron microscopic examination of the ACR-group compared to the control group also showed apparent increase in the numbers PIIs with many lamellar bodies. Pneumocytes type II are the precursors (stem cells) for PIs, which means that their proliferation is a sign of damage to the alveolar wall and trial an attempt to repair the destroyed epithelium ${ }^{[38]}$.

In the current study, at PND 21 the control group appeared with mature alveoli, many alveolar sacs, thin inter-alveolar septa and many relatively thin secondary septa. Ultra structural examination of this group confirmed these findings by revealing the presence of few interstitial cells within the septa and the changes from double capillary layers to single capillary layers in the primary septa. Some studies recorded similar findings who explained that the reduction in septal thickness is due to decreased epithelial and mesenchymal cell proliferations, apoptosis and the formation of multiple focal fusions between the two capillary layers, resulting in the maturation of the double capillary layer within the primary septa into a single capillary layer at this stage ${ }^{[39,40]}$. No LICs could be detected at this stage. Another study clarified that the proliferation of LICs and the maturation of the capillary layer in the rat lung normally stopped on PND 11 [41].

On the other hand, the light microscopic examination of the lungs of the ACR - group on PND 21 revealed an increase in the inter-alveolar sepal thickness. This thickness in the ACR- group was significantly higher than that of the control group, and many interstitial cells were detected upon ultra-structural analysis; many of these interstitial cells had irregular, heterochromatic, apoptotic nuclei with vacuolated cytoplasm. Accumulated collagen fibers and alveolar macrophages with apical pseudopodia were also observed. Additionally, the persistence of double capillary layers in the primary septa was an indication of delayed development. Moreover, another study reported that ACR directly impairs the protein synthesis in fetal tissues through direct effects on RNA, DNA and subcellular protein content ${ }^{[42]}$

The histological findings can be explained by the fact that ACR- induces intracellular generation of oxygen free radicals, which play a crucial role in its toxicity, through lipid peroxidation and other types of oxidative damages ${ }^{[20]}$.

Human and animal exposure to environmental pollutants, such as chemicals and xenobiotics, strongly increase reactive oxygen species (ROS) production, leading to imbalances between ROS generation and neutralization 
that enable ROS to attacking cell membranes and cause devastating damage to biomolecules such as, DNA, lipids and protein ${ }^{[16]}$. In the present study, lung MDA levels were significantly increased and lung GSH levels were significantly decreased in rat after ACR administration at both PND 2 and PND 21. These effects reflect the oxidative action of ACR in the developing lung. ACR is detoxified by conjugation with GSH and inhibits glutathione S-transferase, thus leading to depletion of cellular GSH and changing the redox status of the cells. This change, in turn, may modulate gene expression and result in apoptosis, cell proliferation and cell transformation ${ }^{[43]}$.

Another explanation for the deleterious effects of ACR is mediation of the inflammatory pathway, which was evident in our study based on the significantly elevated expression of serum endocan in ACR-groups compared to control pups on both PND 2 and PND 21. Some scientists postulated that any rise in the tissue expression or serum levels of endocan reflects endothelial activation and neovascularization; indicating the role ACR in the inflammatory processes ${ }^{[44,45]}$. In accordance, the present study showed many congested bod vessels and mononuclear cellular infiltration in lungs of the ACR group.

Furthermore, another study reported that a group of inflammatory intermediaries, such as interleukin-1 and tumor necrosis factor- $\alpha$, can up regulate endocan. Serum endocan expression levels in patients with severe sepsis were relatively high; secretion of inflammatory factors may have prompted the elevations in the serum endocan levels ${ }^{[46]}$. Similarly, another study revealed that intraperitoneal ACR- administration to experimental animals for ten days caused a significant elevations in the levels of inflammatory indicators and; serum cytokines $(\text { TNF- } \alpha, \text { IL-1 } \beta \text { and IL-6 })^{[47]}$.

With regard to these changes, the effect of ASA was evident; our data proved that ASA significantly reduced serum endocan levels and tissue MDA levels and significantly elevated tissue in GSH levels among the ACR+ASA groups.

Ascorbic acid is an important antioxidant that reduces other compounds e.g., ROS and is converted to its oxidized form $^{[48]}$. It was reported that ASA is a naturally occurring organic compound with antioxidant properties, including ROS-trapping and metal-chelating properties that decrease the oxidative damage, DNA damage and inflammation ${ }^{[49]}$. Moreover, ASA is a radical-scavenging antioxidant that can inhibit the induction of pulmonary oxidative stress, injury and inflammation observed in the rat lung after intratracheal instillation of $\mathrm{ZnO}$ nanoparticles ${ }^{[50]}$. Furthermore, several in vivo and in vitro studies have proven that ASA is a useful agent for attenuating the lung injury caused by increased oxidative stress and for, preventing protein damage, cytotoxicity and apoptosis ${ }^{[51]}$.

Overall, according to our findings, concomitant administration of ASA with the ACR improve the histological and ultrastructure appearance of the developing lung by minimizing the, inflammation and lipid peroxidation as well as by increasing GSH activity.

\section{CONCLUSION AND RECOMMENDATION}

Taken together, our results confirmed the harmful alteration of ACR on lung histological structure and elucidated the anti-antioxidant, anti-inflammatory and remodeling effects of ASA. These experimental results should be considered by the pregnant women and breastfeeding mothers to avoid ACR-containing foods .

\section{ABBREVIATIONS}

ACR: Acrylamide, ASA: Ascorbic Acid, MDA: malondialdehyde, GSH: glutathione, PND: Postnatal day.

\section{CONFLICTS OF INTERESTS}

There are no conflicts of interest.

\section{REFERENCES}

1. Tomaszewska E., Dobrowolski P., Puzio I., Prost I., Kurlak P., Sawczuk P., Badzian B., Hulas-stasiak $\mathrm{M}$. and Kostro K. acrylamide-induced prenatal programming of intestine structure in guinea pig. J Physiol Pharmacol. 2014; 65(1): 107-115.

2. Cetin, I., and Laoreti, A. The importance of maternal nutrition for health. J. Pediatr. Neonatal Individ. Med. 2015; 4: e040220.

3. Singh, S.P., Chand, H.S., Langley, R.J., Mishra, N., Barrett, T., Rudolph, K., etal.Gestational Exposure to Sidestream (Secondhand) Cigarette Smoke Promotes Transgenerational Epigenetic Transmission of Exacerbated Allergic Asthma and Bronchopulmonary Dysplasia. J. Immunol. 2017; 198: 3815-3822.

4. Warburton, D., El-Hashash, A., Carraro, G., Tiozzo, C., Sala, F., Rogers, O., De Langhe, S., Kemp, P.J., Riccardi, D., Torday, J. Lung organogenesis, Current topics in developmental biology. Elsevier, 2010; pp. $73-158$.

5. Aras, Duru, et al. "In Vivo acrylamide exposure may cause severe toxicity to mouse oocytes through its metabolite glycidamide." PloS one 2017; $12.2 \mathrm{e} 0172026$.

6. Friedman, M. Chemistry biochemistry and safety of acrylamide. A review J. Agric. Food Chem 2003; 51: 4504-4526.

7. Lin, C.Y., Lee, H.L., Chen, Y.C., Lien, G.W., Lin, L.Y., Wen, L.L., et al. Positive association between urinary levels of 8-hydroxydeoxyguanosine and the acrylamide metabolite $\mathrm{N}$-acetyl-S-(propionamide)cysteine in adolescents and young adults. J. Hazard. Mater. 2013; 261: 372-377.

8. Erkekoglu, P., and Baydar, T. Acrylamide neurotoxicity. Nutr. Neurosci. 2014; 17: 49-57. 
9. Hariri, E., Abboud, M.I., Demirdjian, S., Korfali, S., Mroueh, M., and Taleb, R.I. Carcinogenic and neurotoxic risks of acrylamide and heavy metals from potato and corn chips consumed by the Lebanese population. J. Food Compos. Anal. 2105; 42: 91-97.

10. Dobrovolsky, V.N., Pacheco-Martinez, M.M., McDaniel, L.P., Pearce, M.G., and Ding, W. In vivo genotoxicity assessment of acrylamide and glycidyl methacrylate. Food Chem. Toxicol. 2016; 87: $\quad 120-127$.

11. Duan, X., Wang, Q.C., Chen, K.L., Zhu, C.C., Liu, J., and Sun, S.C. Acrylamide toxic effects on mouse oocyte quality and fertility in vivo. Sci. Rep.2015.

12. Ge, W., Yang, B., Xie, X., Gong, L., Li, Y., Zhang, D., et al. Gestational exposure to acrylamide inhibits mouse placental development in vivo. J. Hazard. Mater.2018

13. Sumner, S.C.J., Williams, C.C., Snyder, R.W., Krol, W.L., Asgharian, B., and Fennell, T.R. Acrylamide: A comparison of metabolism and hemoglobin adducts in rodents following dermal, intraperitoneal, oral, or inhalation exposure. Toxicol. Sci.2003.

14. Fuhr, U., Boettcher, M.I., Kinzig-Schippers, M., Weyer, A., Jetter, A., Lazar, A., et al. Toxicokinetics of acrylamide in humans after ingestion of a defined dose in a test meal to improve risk assessment for acrylamide carcinogenicity. Cancer Epidemiol. Biomarkers Prev 2006.

15. Adams, A., Hamdani, S., Lancker, F. Van, Méjri, S., and Kimpe, N. De. Stability of acrylamide in model systems and its reactivity with selected nucleophiles. Food Res. Int.2010.

16. Abdel-Daim M.M., AbdEldaim, M.A. Hassan, A.G.A. Trigonellafoenum-graecum ameliorates acrylamide-induced toxicity in rats: Roles of oxidative stress, proinflammatory cytokines, and DNA damage, Biochem. Cell Biol.2015.

17. Tong, G.C., Cornwell, W.K., and Means, G.E. Reactions of acrylamide with glutathione and serum albumin. Toxicol. Lett. 2004.

18. Naidu, K. Akhilender. "Vitamin C in human health and disease is still a mystery? An overview." Nutrition journal 2003; 2:7.

19. Balta, S., Mikhailidis, D.P., Demirkol, S., Ozturk, C., Celik, T., Iyisoy, A. Endocan: A novel inflammatory indicator in cardiovascular disease? Atherosclerosis 2015;243:339-43

20. Zhang, X., Zhuang, R., Wu, H., Chen, J., Wang, F., Li, $\mathrm{G}$. and $\mathrm{Wu}, \mathrm{C}$. A novel role of endocan in alleviating LPS-induced acute lung injury. Life sciences 2018; 202, pp.89-97.
21. Li, S., Wang, L., Wang, C., et al. Detection on dynamic changes of endothelial cell specific molecule 1 in acute rejection after renal transplantation. Urology. 2012; 80 (738):e1-8.

22. Dortaj, H., Yadegari, M., Hosseini Sharif Abad, M., AbbasiSarcheshmeh, A., and Anvari, M. Stereological method for assessing the effect of vitamin C, administration on the reduction of acrylamide-induced neurotoxicity. Basic Clin. Neurosci. 2018; 9: 27-34.

23. Wise, L.D., Gordon, L.R., Soper, K.A., Duchai, D.M., and Morrissey, R.E. Developmental neurotoxicity evaluation of acrylamide in Sprague-Dawley rats. Neurotoxicol. Teratol. 1995; 17: 189-198.

24. Leal Filho, M.B., Morandin, R.C., Almeida, A.R. de, Cambiucci, E.C., Metze, K., Borges, G., et al. Hemodynamic parameters and neurogenic pulmonary edema following spinal cord injury: an experimental model. Arq. Neuropsiquiatr. 2005; 63: 990-6.

25. Lepage, G., Munoz, G., Champagne, J., \& Roy, C. C. Preparative steps necessary for the accurate measurement of malondialdehyde by high-performance liquid chromatography. Analytical biochemistry, 1991; 197(2), 277-283.

26. Griffith, O. W. Determination of glutathione and glutathione disulfide using glutathione reductase and 2-vinylpyridine. Analytical biochemistry, 1980; 106(1), 207-212.

27. Bancroft, J. D., and Layton, C. The hematoxylin and eosin. Bancroft's Theory and Practice of Histological Techniques, Expert Consult: Online and Print, 2012; 7th edn. p. 173, Elsevier: Amsterdam, Netherlands

28. Glauert, A., and Lewis, P. Biological specimen preparation for transmission electron microscopy (Princeton University Press 2014.

29. Naruszewicz, M., Zapolska-Downar, D., Kośmider, A., Nowicka, G., Kozłowska-Wojciechowska, M., Vikström, A.S., et al. Chronic intake of potato chips in humans increases the production of reactive oxygen radicals by leukocytes and increases plasma C-reactive protein: A pilot study. Am. J. Clin. Nut. 2009.

30. Bolle, I., Eder, G., Takenaka, S., Ganguly, K., Karrasch, S., Zeller, C. Postnatal lung function in the developing rat. J. Appl. Physiol. 2008; 104: 1167-1176.

31. Sörgel, F., Weissenbacher, R., Kinzig-Schippers, M., Hofmann, A., Illauer, M., Skott, A., Landersdorfer, C. Acrylamide: increased concentrations in homemade food and first evidence of its variable absorption from food, variable metabolism and placental and breast milk transfer in humans. Chemotherapy 2002; 48, 267-274. 
32. Wahba, N.S., Khater, N.A., Shaban, S.F., Hamid, N.H.A. The effect of maternal exposure to di-(2-ethylhexyl)-phthalate on the lung of albino rat offspring: a histological and immunohistochemical study. Egyptian Journal of Histology 2013; 36, 711-724

33. McGowan, S.E., Torday, J.S. The pulmonary lipofibroblast (lipid interstitial cell) and its contributions to alveolar development. Annual review of physiology 1997; 59, 43-62

34. Dickie, R., Wang, Y.T., Butler, J.P., Schulz, H., Tsuda, A. Distribution and quantity of contractile tissue in postnatal development of rat alveolar interstitium. The Anatomical Record: Advances in Integrative Anatomy and Evolutionary Biology 2008; 291, 83-93.

35. Alejandre-Alcázar, M.A., Kwapiszewska, G., Reiss, I., Amarie, O.V., Marsh, L.M., Sevilla-Pérez, J., Wygrecka, M., Eul, B., Köbrich, S., Hesse, M. Hyperoxia modulates TGF- $\beta / B M P$ signaling in a mouse model of bronchopulmonarydysplasia. American Journal of Physiology-Lung Cellular and Molecular Physiology 2007; 292, L537-L549.

36. Zidan, R.A. Effect of long-term administration of amiodarone on rat lung and the possible protective role of vitamin E: a histological and immunohistochemical study. Egyptian Journal of Histology 2011; $34,117-128$

37. Adamson, I., Hedgecock, C., Bowden, D. Epithelial cell-fibroblast interactions in lung injury and repair. The American journal of pathology 1990; 137, 385.

38. Fehrenbach, H. Alveolar epithelial type II cell: defender of the alveolus revisited. Respir Res. $2001 ; 2: 33-46$.

39. Burri, P.H. Structural aspects of postnatal lung development-alveolar formation and growth. Neonatology 2006; 89, 313-322.

40. Ibrahim, O.Y., Selim, A.O. Effects of perinatal nicotine exposure on the development of albino rat's alveoli with special reference to the role of the vascular endothelial growth factor. Egyptian Journal of Histology 2012; 35, 697-710.

41. Pua, Z.J., Stonestreet, B.S., Cullen, A., Shahsafaei, A., Sadowska, G.B., Sunday, M.E. Histochemical analyses of altered fetal lung development following single vs multiple courses of antenatal steroids. Journal of Histochemistry\&Cytochemistry 2005; $53,1469-1479$

42. Klaunig, J., Kamendulis, L. Mechanism of acrylamide induced rodent carcinogenicity.[W:] Chemistry and Safety of Acrylamide in Food. Springer Science+ Businnes Media, Inc. 2005.

43. Schulze-Osthoff, K., Los, M., Baeuerle, P.A. Redox signalling by transcription factors NF- $\mathrm{KB}$ and AP-1 in lymphocytes. Biochemical pharmacology 1995; $50,735-741$.

44. Kali, A., and Shetty, K.R. Endocan: A novel circulating proteoglycan. Indian J. Pharmacol. 2014; 46: 579-583.

45. Torun, A.C., Tutuncu, S., Ustun, B., and Akdemir, H.U. A study of the therapeutic effects of resveratrol on blunt chest trauma-induced acute lung injury in rats and the potential role of endocan as a biomarker of inflammation. Inflammation 2017; 40: 1803-1810.

46. Scherpereel, A., Depontieu, F., Grigoriu, B., Cavestri, B., Tsicopoulos, A., Gentina, T., Jourdain, M., Pugin, J., Tonnel, A.B., Lassalle, P. Endocan a new endothelial marker in human sepsis. Crit Care Med 2006; 34:532-537.

47. Alturfan, A.A., Tozan-Beceren, A., Sehirli, A.O., Demiralp, E., Sener, G., and Omurtag, G.Z. Resveratrol ameliorates oxidative DNA damage and protects against acrylamide-induced oxidative stress in rats. Mol. Biol. Rep. 2012; 39: 4589-4596.

48. Litwack, G. Human biochemistry, Academic Press.2017.

49. Arrigoni, O. and M. C. De Tullio . "Ascorbic acid: much more than just an antioxidant." BiochimicaetBiophysicaActa (BBA) 2002; General Subjects 1569(1-3): 1-9

50. Fukui, H., et al. Ascorbic acid attenuates acute pulmonary oxidative stress and inflammation caused by zinc oxide nanoparticles. Journal of occupational health 2015; 14-0161-OA.

51. Nemenqani, D. "The Ameliorating Effect of Vitamin $\mathrm{C}$ against Cardiopulmonary Toxicity of Zinc Oxide Nanoparticals." Int. Res. J. Appl. Basic Sci.2105; 9: 1102-1109. 


\section{الملخص العربى}

\section{التأثير الضارلتناول الأم للأكريلاميد على تطور الرئة والتأثير المحتمل لحمض التص

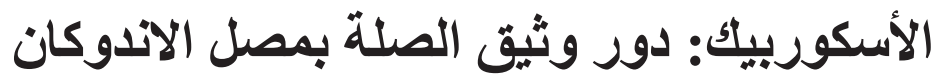

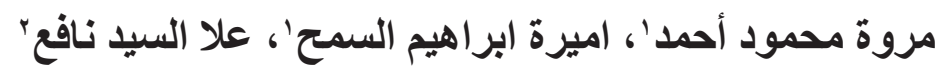 \\ قسم التشريح والأجنة'، والسموم الأكلينيكية، ـ كلية الطب - جامعة الزقازيق}

المقدمة: الأكريلاميد هو ملوث بيئي موجود في البيئة المحيطة والمو اد الغذائية الغنية بالكربو هيدرات و ايضا في دخان التبغ.

الهدف من البحث: كان الهذف من هذه الدر اسة هو تقييم التغير ات النسيجية المحتملة في رئة نسل الجرذان نتيجة تتاول الأمهات لأطعمة غنية بالأكريلاميد والدور الوقائي المحتمل لحمض الأسكوربيك (فيتامين سى). المواد والطرق المستخدمة: قسمت الجرذان الحو امل بشكل عشو ائي الي أربع مجمو عات متساوية، المجمو عة الضـابطة و مجموعة فيتامين سي تلقت فيها الامهات ( . . ( مجم / كجم / يوم) و مجموعة الاكريلاميد والتي تلقت فيها الامهات (•مجم / كجم / يوم) ومجموعة الأكريلاميد + فيتامين سي التي ثلقت الاكريلاميد مع فيتامين سى بنفس الجر عات السابق ذكر ها في المجمو عتين الثانية والثالثة وفي نهاية التجربة تم ذبح عشرة جرذان من كل مجمو عة واسئصسال الرئة ومعالجتها للفحص بالميكرسكوب الضوئى والالكترونى النافذ وعمل دراسة مورفومترية لتحديد تأثير الاكريلاميد وفيتامين سي على تطور رئة الجرذان الوليدة في اليوم الثاني و اليوم الحادي و العشرين بعد الولادة. النتائج: أظهرت النتائج أن تناول الأكريلاميد خلال فترات الحمل والرضاعة زاد بشكل كبير من نسبة الاندوكان ونسبة المالوندايالدهيد في النسيج الرئوي للجرذان الوليدة مع انخفاض معدلات الجلوناثيون جنبا إلى جنب مع التغيرات الهستوباثولوجية الحادة.بينما نتج عن التناول المتزامن للاكريلاميد مع فيتامين سي استعادة البنية النسيجية في الرئة النامية من خلال تأثير فيتامين سى كمضاد للالتهابات ومضاد للأكسدة. الاستنتاج: أسفر إعطاء امهات الجرذان للأكريلاميد إلى تأثير ضار على التركيب النسيجي لرئة لنسل الجرذان من خلال آلياتها المحفزة للأكسدة.بينما ادي التناول المنز امن ل فيتامين سى مع الاكريلاميد إلى تخفيف هذا التأثير السلبي من خلال خصائصده المضادة للأكسدة و المضادة للالتهابات. 